\title{
Function and Molecular Ecology Significance of Two Catechol-Degrading Gene Clusters in Pseudomonas putida ND6
}

\author{
Sanyuan Shi ${ }^{1 \dagger}$, Liu Yang ${ }^{1 \dagger}$, Chen Yang ${ }^{1}$, Shanshan $\mathrm{Li}^{2}$, Hong Zhao ${ }^{3}$, Lu Ren ${ }^{1}$, Xiaokang Wang', \\ Fuping $\mathrm{Lu}^{1}$, Ying $\mathrm{Li}^{4 *}$, and Huabing $\mathrm{Zhao}^{1 *}$ \\ ${ }^{1}$ Tianjin Key Laboratory of Industrial Microbiology, College of Biotechnology, Tianjin University of Science and \\ Technology, Tianjin 300457, P.R. China \\ ${ }^{2}$ Department of Environmental Science and Engineering, Xi'an Jiaotong University, Xi'an 710048, P.R. China \\ ${ }^{3}$ Tianjin Entry-Exit Inspection and Quarantine Bureau, Tianjin 300457, P.R. China \\ ${ }^{4}$ China Animal Disease Control Center, Beijing 100000, P.R. China
}

\begin{abstract}
Many bacteria metabolize aromatic compounds via catechol as a catabolic intermediate, and possess multiple genes or clusters encoding catechol-cleavage enzymes. The presence of multiple isozyme-encoding genes is a widespread phenomenon that seems to give the carrying strains a selective advantage in the natural environment over those with only a single copy. In the naphthalene-degrading strain Pseudomonas putida ND6, catechol can be converted into intermediates of the tricarboxylic acid cycle via either the ortho- or meta-cleavage pathways. In this study, we demonstrated that the catechol ortho-cleavage pathway genes (cat $B_{1} C_{l} A_{\text {, and }}$ cat $B_{\| \prime} C_{\mid l} A_{\| l}$ ) on the chromosome play an important role. The cat, and cat ${ }_{\| \prime}$ operons are co-transcribed, whereas cat $A_{\text {, }}$ and $c a t A_{/ /}$are under independent transcriptional regulation. We examined the binding of regulatory proteins to promoters. In the presence of cis-cis-muconate, a well-studied inducer of the cat gene cluster, Cat $R_{1}$ and Cat $_{\| \mid}$occupy an additional downstream site, designated as the activation binding site. Notably, CatR $R_{1}$ binds to both the cat , and cat ${ }_{\|}$promoters with high affinity, while Cat $_{\| \mid}$binds weakly. This is likely caused by a $\mathrm{T}$ to $\mathrm{G}$ mutation in the G/T-N $\mathrm{N}_{11}-\mathrm{A}$ motif. Specifically, we found that Cat $R_{1}$ and $C$ at $R_{\| \mid}$regulate cat $B_{\mid} C_{l} A_{\text {, and }}$ cat $B_{\| \mid} C_{\| l} A_{\| \mid}$in a cooperative manner, which provides new insights into naphthalene degradation.
\end{abstract}

Received: September 16, 2020 Accepted: December 8, 2020

First published online: December 11, 2020

*Corresponding authors H. Zhao

Phone: $+86-22-60601958$ Fax: +86-22-60602298 E-mail: zhaohuabing@tust. edu.cn

Phone: +86-10-59198969 Fax: +86-10-59198969

E-mail: liyinglucky2001@ aliyun.com

${ }^{\dagger}$ These authors contributed equally to this work.

pISSN 1017-7825 eISSN 1738-8872

Copyright(C) 2021 by The Korean Society for Microbiology and Biotechnology
Keywords: Pseudomonas putida ND6, catechol ortho-cleavage pathway, $C a t R_{l}$ and $\operatorname{Cat}_{\|}, \operatorname{cat}_{1} C_{l} A_{l}$ and cat $B_{\| /} C_{\| /} A_{\|}$operons, cross-regulation, evolution of catabolic pathways

\section{Introduction}

A number of aerobic biodegradation pathways of aromatic compounds like benzoate, aniline, phenol, pyrene and naphthalene converge at the catechol ring cleavage reaction, and eventually generate intermediates of the tricarboxylic acid cycle through two different routes [1-3]. The catechol meta-cleavage pathway is usually encoded by the nah and $x y l$ genes on plasmids, while the catechol ortho-cleavage pathway is usually determined by the chromosomal cat and ben genes [4-9]. Ortho-cleavage is followed by further steps of the $\beta$-ketoadipate pathway which is catalyzed by the three enzymes catechol 1,2-dioxygenase (C12O, E.C. 1.13.11.1) (catA), cis, cis-muconatelactonizing enzyme I (catB), and muconolactone isomerase ( $c a t C)$. The expression of this operon is regulated by CatR, and is induced by cis, cis-muconate (CCM) [9-15].

Several research groups have found that bacteria possess multiple catechol ortho-cleavage genes or clusters, which might indicate the importance of keeping the intracellular concentration of catechol and its derivatives low $[6,7,16-20]$. Notably, the strains with multiple catechol dioxygenase genes can usually grow on many more aromatic compounds than strains with one dioxygenase gene $[14,21]$. Different enzymatic properties and induction patterns of $\mathrm{C} 12 \mathrm{O}$ isozymes may be responsible for the metabolism of different substrates [22]. For example, three different $\mathrm{C} 12 \mathrm{O}$ isozymes encoded by cat $A$, cat $A_{I}$ and $c a t A_{I I}$ in the naphthalene-degrading strain Pseudomonas putida ND6 were found to have different enzymatic properties [17]. Burkholderia sp. strain TH2, a 2-chlorobenzoate (2CB)-degrading bacterium, metabolizes benzoate $(\mathrm{BA})$ and $2 \mathrm{CB}$ via two catechol orthocleavage pathways $\left(c a t_{1}\right.$ and $\left.c a t_{2}\right)$. Interestingly, the inducer of $c a t A_{1}$ was found to be $\mathrm{BA}$, and not $2 \mathrm{CB}$. It was also found that CCM or its metabolite acts as an inducer for $c a t A_{2}$. These results suggest that although cat $_{2}$ genes are not indispensable for growth of TH2 on 2CB, they are advantageous [20]. Murakami et al. reported that the anilineassimilating bacterium Frateuria sp. ANA-18 has two cat clusters, which are respectively located on the 
chromosome and the large plasmid [19]. Two CatR proteins that differ in their binding affinity for the catB promoters control the expression of the two cat gene clusters, which is affected by the concentration of CCM. The $c a t B_{1}$ promoter was shown to be active in the presence of CCM, while the $c a t B_{2}$ promoter was activated only at low concentrations of CCM [23]. Hence, the presence of multiple catechol ortho-cleavage genes and pathways in the same cell seems to be a widespread phenomenon that gives the host strains a selective advantage in the natural environment. However, the research on function, regulation and evolutionary significance of these genes and clusters should be further intensified.

P. putida strain ND6, which was isolated by our group from industrial wastewater in Tianjin, China, was capable of growth on naphthalene as the sole carbon and energy source, and successfully degraded $98 \%$ of $2 \mathrm{~g} / \mathrm{l}$ naphthalene in mineral medium in $48 \mathrm{~h}$. Similar to other described strains [24-26], ND6 possesses an integrated naphthalene-degrading pathway, and catabolizes catechol through the meta-cleavage pathway. However, a unique feature of ND6 exists in the presence of two catechol ortho-cleavage pathways, encoded by $c a t R_{I} B_{I} C_{I} A_{I}$ and $\operatorname{cat}_{I I} B_{I I} C_{I I} A_{I I}$ on the chromosome, in addition to the typical catechol meta-cleavage pathway on the plasmid. We investigated the cellular responses of $P$. putida ND6 grown in medium with 2 (normal concentration) and $4 \mathrm{~g} / \mathrm{l}$ naphthalene (high concentration) using a quantitative proteomics-based approach. Comparative analysis of the proteomic data indicated that the expression levels of Cat $\mathrm{A}_{\mathrm{I}}, \mathrm{Cat}_{\mathrm{I}}$, and Cat $\mathrm{B}_{\mathrm{II}}$, which are involved in the catechol ortho-cleavage pathway, were upregulated [27]. This demonstrated that $P$. putida ND6 is able to survive in the presence of high naphthalene concentrations mainly because of the duplicated catechol ortho-cleavage operons. The two ortho-cleavage operons are regulated by the LysR-type regulatory proteins $\mathrm{Cat}_{\mathrm{I}}$ and $\mathrm{Cat}_{\mathrm{II}}$, respectively. The distance between the two clusters was about $754 \mathrm{~kb}$, and their sequence identity was $73.57 \%$. Based on the previous work in our laboratory, we hypothesized that these two gene clusters have different functions and evolutionary origins, and might regulate each other via genetic cross-talk. In this paper, we compared the function, regulation and evolutionary significance of the two catechol ortho-cleavage gene clusters in P. putida strain ND6.

\section{Materials and Methods}

Bacterial Strains, Culture Conditions, Plasmids, Primers and DNA Manipulations

P. putida strain ND6 and mutants were cultured at $30^{\circ} \mathrm{C}$ and $180 \mathrm{rpm}$ in Luria-Bertani (LB), or in mineral medium (MMB) with $0.2 \%$ naphthalene or $0.2 \%$ glucose as the carbon source. Escherichia coli strains were grown

Table 1. Strains and plasmids used in this study.

\begin{tabular}{|c|c|c|c|}
\hline \multicolumn{2}{|c|}{ Strains/plasmids } & Genotype and description & \multirow{2}{*}{$\begin{array}{c}\begin{array}{c}\text { Source/ } \\
\text { reference }\end{array} \\
\text { Novagen }\end{array}$} \\
\hline E. coli & JM109 & Cloning strain & \\
\hline & S17-1 & recA pro hsdR RP4-2-Tc::Mu-Km::Tn7; donor strain for conjugation; & {$[28]$} \\
\hline & BL21 & Expression strain & Novagen \\
\hline \multirow[t]{12}{*}{ P. putida } & ND6 & $\mathrm{Cb}^{\mathrm{r}}$ & {$[16]$} \\
\hline & ND6- $\Delta c a t R_{I}$ & cat $_{I}$ mutant of ND6; $\mathrm{Cb}^{\mathrm{r}}, \mathrm{Kan}^{\mathrm{r}}$ & This study \\
\hline & ND6- $\Delta c a t R_{I I}$ & cat $_{I I}$ mutant of ND6; $\mathrm{Cb}^{\mathrm{r}}, \mathrm{Kan}^{\mathrm{r}}$ & This study \\
\hline & ND6- $\Delta c a t A$ & catA mutant of ND6; $\mathrm{Cb}^{\mathrm{r}}, \mathrm{Kan}^{\mathrm{r}}$ & This study \\
\hline & ND6- $\Delta c a t A n a h H$ & cat $A$ and $n a h H$ mutant of ND6; $\mathrm{Cb}^{\mathrm{r}}, \mathrm{Kan}^{\mathrm{r}}, \mathrm{Cm}^{\mathrm{r}}$ & This study \\
\hline & $\mathrm{NC}$ & ND6 containing plasmid pDN19lac $\Omega ; \mathrm{Cb}^{\mathrm{r}}, \mathrm{Sp}^{\mathrm{r}}, \mathrm{Sm}^{\mathrm{r}}$ & This study \\
\hline & NP1 & ND6 containing plasmid pDB1; $\mathrm{Cb}^{\mathrm{r}}, \mathrm{Sp}^{\mathrm{r}}, \mathrm{Sm}^{\mathrm{r}}$ & This study \\
\hline & NP2 & ND6 containing plasmid pDB2; $\mathrm{Cb}^{\mathrm{r}}, \mathrm{Sp}^{\mathrm{r}}, \mathrm{Sm}^{\mathrm{r}}$ & This study \\
\hline & ND1P1 & ND6- $\Delta$ cat $R_{I}$ containing plasmid pDB1; $\mathrm{Cb}^{\mathrm{r}}, \mathrm{Kan}^{\mathrm{r}}, \mathrm{Sp}^{\mathrm{r}}, \mathrm{Sm}^{\mathrm{r}}$ & This study \\
\hline & ND1P2 & ND6- $\Delta$ cat $R_{I}$ containing plasmid pDB2; $\mathrm{Cb}^{\mathrm{r}}, \mathrm{Kan}^{\mathrm{r}}, \mathrm{Sp}^{\mathrm{r}}, \mathrm{Sm}^{\mathrm{r}}$ & This study \\
\hline & ND2P1 & ND6- $\Delta$ cat $R_{I I}$ containing plasmid pDB1; $\mathrm{Cb}^{\mathrm{r}}, \mathrm{Kan}^{\mathrm{r}}, \mathrm{Sp}^{\mathrm{r}}, \mathrm{Sm}^{\mathrm{r}}$ & This study \\
\hline & ND2P2 & ND6- $\Delta$ cat $R_{I I}$ containing plasmid pDB2; $\mathrm{Cb}^{\mathrm{r}}, \mathrm{Kan}^{\mathrm{r}}, \mathrm{Sp}^{\mathrm{r}}, \mathrm{Sm}^{\mathrm{r}}$ & This study \\
\hline \multirow[t]{15}{*}{ Plasmid } & pUC18-T simple & Cloning vector; $\mathrm{Amp}^{\mathrm{r}}$ & TransGen \\
\hline & pEX18Tc & Gene replacement; Tet $^{\mathrm{r}}$, oriT $^{+} \operatorname{sacB}^{+}$ & {$[29]$} \\
\hline & $\mathrm{pDN} 19$ lac $\Omega$ & Broad host range shuttle vector; $\mathrm{Sp}^{\mathrm{r}}, \mathrm{Sm}^{\mathrm{r}}$ & {$[30]$} \\
\hline & pEASY-Blunt & Source of kan gene; $\mathrm{Amp}^{\mathrm{r}}, \mathrm{Kan}^{\mathrm{r}}$ & TransGen \\
\hline & pXMJ19 & Source of cat gene; $\mathrm{Amp}^{\mathrm{r}}, \mathrm{Cm}^{\mathrm{r}}$ & TransGen \\
\hline & pEX18Tc- $\mathrm{R}_{\mathrm{I}} \mathrm{Km}$ & pEX18Tc with $\Delta c a t R_{I}:: \operatorname{Kan}^{\mathrm{r}} ; \operatorname{Tet}^{\mathrm{r}}$ & This study \\
\hline & $\mathrm{pEX} 18 \mathrm{Tc}-\mathrm{R}_{\mathrm{II}} \mathrm{Km}$ & pEX18Tc with $\Delta c a t R_{I I}: \operatorname{Kan}^{\mathrm{r}} ; \operatorname{Tet}^{\mathrm{r}}$ & This study \\
\hline & pEX18Tc-AKm & pEX18Tc with $\Delta c a t A:: \operatorname{Kan}^{\mathrm{r}} ; \operatorname{Tet}^{\mathrm{r}}$ & This study \\
\hline & pEX18Tc-HCm & pEX18Tc with $\Delta n a h H:: \mathrm{Cm}^{\mathrm{r}} ; \mathrm{Tet}^{\mathrm{r}}$ & This study \\
\hline & pEX5-catR & $\mathrm{CatR}_{\mathrm{I}}$ protein expression vector; $\operatorname{Kan}^{\mathrm{r}}$ & This study \\
\hline & pEX5-catR ${ }_{I I}$ & CatR $_{\text {II }}$ protein expression vector; Kan $^{r}$ & This study \\
\hline & pUC19c-catB ${ }_{I}$ & pUC19c with cat $B_{I}$ promoter; $\mathrm{Amp}^{\mathrm{r}}$ & This study \\
\hline & pUC19c-catB & pUC $19 \mathrm{c}$ with cat $B_{I I}$ promoter; $\mathrm{Amp}^{\mathrm{r}}$ & This study \\
\hline & $\mathrm{pDB}_{\mathrm{I}}$ & cat $_{I}$ promoter inserted between the EcoRI and BamHI sites of pDN19lac $\Omega ; \mathrm{Sp}^{\mathrm{r}}, \mathrm{Sm}^{\mathrm{r}}$ & This study \\
\hline & $\mathrm{pDB}_{\mathrm{II}}$ & cat $_{I I}$ promoter inserted between the EcoRI and BamHI sites of pDN19lac $\Omega ; \mathrm{Sp}^{\mathrm{r}}, \mathrm{Sm}^{\mathrm{r}}$ & This study \\
\hline
\end{tabular}

${ }^{\star} \mathrm{Cb}^{\mathrm{r}}$, carbenicillin resistant; $\mathrm{Kan}^{\mathrm{r}}$, kanamycin resistant; $\mathrm{Cm}^{\mathrm{r}}$, Chloramphenicol resistant; $\mathrm{Sp}^{\mathrm{r}}$, spectinomycin resistant; Sm ${ }^{\mathrm{r}}$, streptomycin resistant; $\mathrm{Amp}^{\mathrm{r}}$, ampicillin resistant; $\mathrm{Tet}^{\mathrm{r}}$, tetracycline resistant; $\mathrm{Gm}^{\mathrm{r}}$, gentamicin resistant. 
in $\mathrm{LB}$ at $37^{\circ} \mathrm{C}$ and $180 \mathrm{rpm}$. Where appropriate, spectinomycin (Sp; $\left.50 \mathrm{mg} / \mathrm{l}\right)$, streptomycin ( $\left.\mathrm{Sm} ; 50 \mathrm{mg} / \mathrm{l}\right)$, chloramphenicol (Cm; $25 \mathrm{mg} / \mathrm{l}$ ), ampicillin (Amp; $50 \mathrm{mg} / \mathrm{l})$, kanamycin (Kan; $50 \mathrm{mg} / \mathrm{l})$, carbenicillin (Cb; $75 \mathrm{mg} / \mathrm{l}$ ), tetracycline (Tet; $10 \mathrm{mg} / \mathrm{l})$, or gentamicin $(\mathrm{Gm} ; 10 \mathrm{mg} / \mathrm{l})$ was added for selection.

The bacterial strains, plasmids, and primers used in the present study are listed in Tables 1 and 2. All DNA manipulations were performed according to standard procedures [31]. Restriction enzymes, DNA polymerase and T4 DNA ligase were used in accordance with the manufacturers' specifications.

Table 2. Primers used in this study.

\begin{tabular}{|c|c|c|}
\hline $\begin{array}{l}\text { Primer } \\
\text { name }\end{array}$ & Sequence $\left(5^{\prime}-3^{\prime}\right)$ & Description \\
\hline$\overline{\mathrm{R}_{\mathrm{I}} \mathrm{L}-\mathrm{F}}$ & GTGATGTGGCCGAATGCCTC & Used in the creation of ND6- $\Delta$ cat $R_{I}$ mutant \\
\hline $\mathrm{R}_{\mathrm{I}} \mathrm{L}-\mathrm{R}$ & CGGCATGAGCATTCGTGTC & Used in the creation of ND6- $\Delta c a t R_{I}$ mutant \\
\hline $\mathrm{R}_{\mathrm{I}} \mathrm{R}-\mathrm{F}$ & GGCCGAAGCCAATGTCGA & Used in the creation of ND6- $\Delta c a t R_{I}$ mutant \\
\hline $\mathrm{R}_{\mathrm{I}} \mathrm{R}-\mathrm{R}$ & GCTTTCGATGCCGGACTTG & Used in the creation of ND6- $\Delta c a t R_{I}$ mutant \\
\hline $\mathrm{R}_{\mathrm{II}} \mathrm{L}-\mathrm{F}$ & GACGGCCAAGTCGATGGTG & Used in the creation of ND6- $\Delta c a t R_{I I}$ mutant \\
\hline $\mathrm{R}_{\mathrm{II}} \mathrm{L}-\mathrm{R}$ & TAGGCCAGCCGATATCGCT & Used in the creation of ND6- $\Delta c a t R_{I I}$ mutant \\
\hline $\mathrm{R}_{\mathrm{II}} \mathrm{R}-\mathrm{F}$ & CCTGATAGATAGCCGCGTCG & Used in the creation of ND6- $\Delta c a t R_{I I}$ mutant \\
\hline $\mathrm{R}_{\mathrm{II}} \mathrm{R}-\mathrm{R}$ & AGCAAGCGAAGAATGACCAAGG & Used in the creation of ND6- $\Delta c a t R_{I I}$ mutant \\
\hline AL-F & GGGCCGCTTGATCAACGTCGT & Used in the creation of ND6- $\triangle A H$ mutant \\
\hline AL-R & ATCTCAGGCAGGTTGGAAATAG & Used in the creation of ND6- $\triangle A H$ mutant \\
\hline AR-F & CAGTCCGAATACAACCTGCGC & Used in the creation of ND6- $\triangle A H$ mutant \\
\hline AR-R & CCGAAGGCGACAAAGCTGGAG & Used in the creation of ND6- $\triangle A H$ mutant \\
\hline HL-F & GCGCCGCTGGACGTGACAATGC & Used in the creation of ND6- $\triangle A H$ mutant \\
\hline HL-R & TCCAGTACACGCAGTTGCACG & Used in the creation of ND6- $\triangle A H$ mutant \\
\hline HR-F & TTATTTCTTCGACCCGTCCGG & Used in the creation of ND6- $\triangle A H$ mutant \\
\hline HR-R & GGCCGGTCCGACTTTCCAGGT & Used in the creation of ND6- $\triangle A H$ mutant \\
\hline kan-F & GGGCGGTTTTATGGACAGC & Used in the creation of ND6- $\Delta c a t R_{I}$, ND6- $\Delta c a t R_{I I}$, ND6- $\Delta$ AH mutant \\
\hline kan-R & CGGTGCTCAACGGGAATC & Used in the creation of ND6- $\Delta c a t R_{I}, \mathrm{ND6}-\Delta c a t R_{I I}, \mathrm{ND6}-\Delta A H$ mutant \\
\hline cat-F & CTTAAAAAAATTACGCCCCGC & Used in the creation of ND6- $\triangle A H$ mutant \\
\hline cat-R & TGATCGGCACGTAAGAGGTTC & Used in the creation of ND6- $\triangle A H$ mutant \\
\hline catB $_{\mathrm{I}} \mathrm{P}-\mathrm{F}$ & AGCACGGTGCAGGTCTGTTC & Used for construction $c a t B_{I}-$ lacZ fusions \\
\hline catB $_{\mathrm{I}} \mathrm{P}-\mathrm{R}$ & GCCCGAGTGATGCGTTTAC & Used for construction $c a t B_{I}-$ lacZ fusions \\
\hline catB $_{\mathrm{II}} \mathrm{P}-\mathrm{F}$ & CAAGCTGTTTGAGCAAGGTGTC & Used for construction $c a t B_{I I}$-lacZ fusions \\
\hline catB $_{\mathrm{II}} \mathrm{P}-\mathrm{R}$ & TAAGGCATCAATACCCATCG & Used for construction $c a t B_{I I}$-lacZ fusions \\
\hline CatR $_{\mathrm{I}}-\mathrm{F}$ & ACTTGATTGTTGAAGGATT & Used for Cat $\mathrm{R}_{\mathrm{I}}$ protein expression \\
\hline $\mathrm{CatR}_{\mathrm{I}}-\mathrm{R}$ & TCAGAGTGCCTGTTGCTC & Used for Cat $\mathrm{R}_{\mathrm{I}}$ protein expression \\
\hline CatR $_{\mathrm{II}}-\mathrm{F}$ & GTGGAGCTCAGGCAT & Used for CatR $\mathrm{R}_{\mathrm{II}}$ protein expression \\
\hline CatR $_{\mathrm{II}}-\mathrm{R}$ & TTATCGATTGATGGTCG & Used for CatR $\mathrm{R}_{\mathrm{II}}$ protein expression \\
\hline q16S-F & CGGATCGCAGTCTGCAACTC & 16s gene for RT-qPCR \\
\hline q16S-R & ACACCGTGGTAACCGTCCTCC & 16 s gene for RT-qPCR \\
\hline qcat $A_{I}-F$ & AGGAATGCCTGGACCTGCTCG & $\operatorname{cat} A_{I}$ gene amplification for RT-qPCR \\
\hline $\mathrm{qcat}_{\mathrm{I}}-\mathrm{R}$ & CGAATGACAACTCGGCAAAGCG & $\operatorname{cat}_{I}$ gene amplificationfor RT-qPCR \\
\hline qcatB $_{\mathrm{I}}-\mathrm{F}$ & CTGGCATTGCCTTGTACGG & cat $B_{I}$ gene amplification for RT-qPCR \\
\hline qcatB $_{\mathrm{I}}-\mathrm{R}$ & AGGCGCTGTTCGTCCAATG & cat $B_{I}$ gene amplification for RT-qPCR \\
\hline qcatC $_{\mathrm{I}}-\mathrm{F}$ & ACATGGACCCGGCCAAGG & cat $_{I}$ gene amplification for RT-qPCR \\
\hline $\mathrm{qcatC}_{\mathrm{I}}-\mathrm{R}$ & TCAGCGATCGTCGCTGTG & cat $_{I}$ gene amplification for RT-qPCR \\
\hline $\mathrm{qcat}_{\mathrm{II}}-\mathrm{F}$ & AAGGGCTAATCGGCGAAGTG & cat $A_{I I}$ gene amplification for RT-qPCR \\
\hline $\mathrm{qcat}_{\mathrm{II}}-\mathrm{R}$ & GCTGTTCGGCAGTCTCAACC & cat $A_{\text {II }}$ gene amplification for RT-qPCR \\
\hline $\mathrm{qcatB}_{\mathrm{II}}-\mathrm{F}$ & GGTGCGGCTCAATCAACG & cat $_{I I}$ gene amplification for RT-qPCR \\
\hline $\mathrm{qcatB}_{\mathrm{II}}-\mathrm{R}$ & GCCTGGGCTATCTGGGCAG & cat $_{I I}$ gene amplification for RT-qPCR \\
\hline $\mathrm{qcatC}_{\mathrm{II}}-\mathrm{F}$ & CAAGTGGCTGCCCGCTTG & cat $_{\text {II }}$ gene amplification for RT-qPCR \\
\hline $\mathrm{qcatC}_{\mathrm{II}}-\mathrm{R}$ & AGCGCTTCGACACTGTCCACA & cat $_{I I}$ gene amplification for RT-qPCR \\
\hline $\operatorname{catB}_{\mathrm{I}} \mathrm{C}_{\mathrm{I}}-\mathrm{F}$ & GGGCCTGACATTGGACGAAC & The region of cat $B_{I}$ gene and $c a t C_{I}$ gene; RT-PCR \\
\hline $\operatorname{catB}_{\mathrm{I}} \mathrm{C}_{\mathrm{I}}-\mathrm{R}$ & ACACAGGCCGTCGACCTCA & The region of $c a t B_{I}$ gene and $c a t C_{I}$ gene; RT-PCR \\
\hline catC $\mathrm{A}_{\mathrm{I}}-\mathrm{F}$ & CGTACATGGACATTGAGGTCGA & The region of $c a t C_{I}$ gene and $c a t A_{I}$ gene; RT-PCR \\
\hline cat $C_{I} A_{I}-R$ & AGGTCGAGGAAGTGCTCGATG & The region of $\operatorname{cat} C_{I}$ gene and $\operatorname{cat} A_{I}$ gene; RT-PCR \\
\hline $\operatorname{catB}_{\mathrm{II}} \mathrm{C}_{\mathrm{II}}-\mathrm{F}$ & GATCAGCTGCAATGGCACAC & The region of $c a t B_{I I}$ gene and $c a t C_{2}$ gene; RT-PCR \\
\hline $\operatorname{catB}_{\mathrm{II}} \mathrm{C}_{\mathrm{II}}-\mathrm{R}$ & AGCGCTTCGACACTGTCC & The region of $c a t B_{I I}$ gene and $c a t C_{I I}$ gene; RT-PCR \\
\hline $\operatorname{catC}_{\mathrm{II}} \mathrm{A}_{\mathrm{II}}-\mathrm{F}$ & CAAGTGGCTGCCCGCTT & The region of $\operatorname{cat} C_{I I}$ gene and $c a t A_{I I}$ gene; RT-PCR \\
\hline $\operatorname{catC}_{\mathrm{II}} \mathrm{A}_{\mathrm{II}}-\mathrm{R}$ & CGATAAACAACGTGGTGGCAAC & The region of $c a t C_{I I}$ gene and $c a t A_{I I}$ gene; RT-PCR \\
\hline M13F-11 & CGCCAGGGTTTTCCCAGTCACGAC & $\begin{array}{l}\text { TaqMan primer used for } c a t B_{I} \text { or } c a t B_{I I} \text { EMSA and DNase I } \\
\text { footprinting template }\end{array}$ \\
\hline M13R-12 & AGCGGATAACAATTTCACACAGGA & $\begin{array}{l}\text { TaqMan primer used for } c a t B_{I} \text { or } c a t B_{I I} \text { EMSA and DNase I } \\
\text { footprinting template }\end{array}$ \\
\hline catB $_{\mathrm{I}}-$ pe & TGTGTTCAATCAGCGCGCTTGTC & $\mathrm{CatB}_{I}$ gene-specific primer, Primer extension \\
\hline catB $_{\text {II }}$-pe & GCTGCTGTCATTTCAGGTTCCATC & $\mathrm{CatB}_{\text {II }}$ gene-specific primer, Primer extension \\
\hline
\end{tabular}




\section{Construction of $P$. putida ND6 Mutants}

The suicide vector pEX18Tc was used for gene replacement in Pseudomonas. The $c a t R_{I}$ replacement vector pEX18Tc- $R_{1} \mathrm{Km}$ was constructed by inserting the $\operatorname{Kan}^{\mathrm{r}}$ cassette into the cat $R_{I}$ gene in the pEX18Tc vector to generate a partial deletion from 226 to $440 \mathrm{bp}$. Similarly, the $c a t R_{I I}$ replacement vector pEX18Tc- $\mathrm{R}_{\mathrm{II}} \mathrm{Km}$ was constructed by replacing 335 to $407 \mathrm{bp}$, and the cat $A$ replacement vector pEX18Tc-AKm by replacing between 10 to $514 \mathrm{bp}$. The knockout plasmids pEX18Tc- $\mathrm{R}_{\mathrm{I}} \mathrm{Km}$, pEX18Tc- $\mathrm{R}_{\mathrm{II}} \mathrm{Km}$, and pEX18Tc-AKm were transferred from E. coli S17-1 into P. putida ND6 by intergeneric conjugation, followed by selection on $\mathrm{LB}+\mathrm{Cb}+\mathrm{Kan}$ medium with $20 \%$ sucrose to generate the $c a t R_{I}, c a t R_{I I}$ and cat $A$ mutants. The resulting mutant strains were named $P$. putida ND6- $\Delta c a t R_{I}$, ND6- $\Delta c a t R_{I I}$, and ND6- $\Delta c a t A$, respectively.

The $n a h H$ replacement vector pEX18Tc-HCm was constructed by inserting the $\mathrm{Cm}^{\mathrm{r}}$ cassette into the internally deleted nahH gene in the pEX18Tc vector, replacing the sequence between 204 to $742 \mathrm{bp}$. Finally, the P. putida strain ND6- $\Delta$ catAnahH was obtained.

Time-Courses of Growth, Naphthalene Degradation, and Catechol Dioxygenase Activity

The wild-type ND6, as well as the mutants ND6- $\Delta c a t R_{I}, \mathrm{ND6}-\Delta c a t R_{I I}$ and ND6- $\Delta c a t A n a h H$, were individually grown in MMB medium with $0.2 \%$ naphthalene. Bacterial growth was monitored by measuring the optical density at $600 \mathrm{~nm}$. Naphthalene in the culture broth was extracted twice with an equal volume of dichloromethane, and its concentration was measured according to a published method [32]. The activity of catechol dioxygenases (C12O and C23O) was assayed as described previously [17].

\section{Quantitative Real-Time PCR (RT-qPCR)}

The wild-type ND6, as well as the ND6- $\Delta c a t R_{I}$ and ND6- $\Delta c a t R_{I I}$ mutants were cultured at $30^{\circ} \mathrm{C}$ in MMB with glucose or naphthalene. Cells were harvested at $25 \mathrm{~h}$ (end of the exponential growth phase) and washed with TE buffer. RNA was extracted using the RNAprep Pure Bacteria Kit (Tiangen Biotech, China) and reversetranscribed into cDNA using the FastKing RT Kit (with gDNase) (Tiangen Biotech). The RT-qPCR was performed following the instructions of the Green Premix Ex Taq II Kit. All RT-qPCR reactions were conducted in three biological and three technical replicates.

Plasmid standards were used for absolute quantification of the corresponding gene fragments. The plasmid copy number was determined according to the molar mass derived from the plasmid and amplicon sequences [33]. For each standard sample, the RT-qPCR system was used to measure the cycle threshold values, which were used to draw a standard curve for each isoform by plotting the cycle threshold values versus the log value of the transcript copy number. Regression equations generated by the system software were used to calculate the transcript copy number for each isoform in each test sample, which was normalized to the value of the 16S rRNA and expressed as the absolute copy number per 1000 copies of $16 \mathrm{~S}$ transcript. The $95 \%$ confidence interval was used to assess the significance of copy number differences, and analysis of variance (ANOVA) was used to assess the significance of the threshold cycle values.

\section{Expression and Purification of Cat $\mathrm{R}_{\mathrm{I}}$ and $\mathrm{CatR}_{\mathrm{II}}$}

E. coli $\mathrm{BL} 21$ carrying the CatR $\mathrm{R}_{\mathrm{I}}$ and $\mathrm{CatR}_{\mathrm{II}}$ expression plasmids pEX5-Cat $\mathrm{R}_{\mathrm{I}}$ and $\mathrm{pEX} 5-\mathrm{Cat}_{\mathrm{II}}$ were grown overnight in LB medium with kanamycin. The expression was induced overnight at $16^{\circ} \mathrm{C}$ by adding a final concentration of $0.5 \mathrm{mM}$ isopropyl- $\beta$-D-thiogalactopyranoside (IPTG). To purify Cat $\mathrm{R}_{\mathrm{I}}$ and $\mathrm{CatR}_{\mathrm{II}}$, cell pellets obtained from 1 liter cultures were collected at $13,000 \times \mathrm{g}$ for $3 \mathrm{~min}$ at $4^{\circ} \mathrm{C}$ and resuspended in $40 \mathrm{ml}$ of binding buffer (50 mM sodium phosphate, $0.3 \mathrm{M} \mathrm{NaCl}, \mathrm{pH} 7.4$ ), and sonicated. The clarified lysate was applied to a nickelnitrilotriacetic acid (NTA) affinity column and allowed to bind for $1 \mathrm{~h}$, followed by washing with binding buffer containing $10 \mathrm{mM}, 30 \mathrm{mM}$ and $60 \mathrm{mM}$ imidazole, and eluting with binding buffer containing $500 \mathrm{mM}$ imidazole. The collected fractions were determined by sodium dodecyl sulfate-polyacrylamide gel electrophoresis (SDSPAGE). The desalination column Sephadex G-25 (GE, USA) was used to remove the imidazole, and yielded the purified protein. The protein was stored in glycerol at $-20^{\circ} \mathrm{C}$.

\section{Primer-Extension Assay}

The primer extension assay was carried out according to the protocol of Fekete $e t$ al., as published previously [34].

\section{Electrophoretic Mobility Shift Assay (EMSA)}

The fluorescent 6 -fluorescein amidite (FAM)-labeled probes were prepared by amplifying the promoter regions of pUC19c-catB $B_{I}$ and $\mathrm{pUC19c}-\mathrm{catB}_{\mathrm{II}}$ by PCR using the primers M13F-11 and M13R-12 (Table 2). The Wizard SV Gel and PCR Clean-Up System (Promega) was used to purify the resulting FAM-labeled probes, which were then quantified using a NanoDrop 2000C instrument (Thermo Fisher Scientifc, USA). The EMSA samples comprised $20 \mu \mathrm{l}$ of $50 \mathrm{mM}$ Tris-HCl [pH 8.0], $100 \mathrm{mM} \mathrm{KCl}, 2.5 \mathrm{mM} \mathrm{MgCl}_{2}, 0.2 \mathrm{mM}$ dithiothreitol (DTT), with $2 \mu \mathrm{g}$ salmon sperm DNA and $10 \%$ glycerol, as well as $40 \mathrm{ng}$ of the probe and the indicated DNA-binding proteins. After incubation for $30 \mathrm{~min}$ at $30^{\circ} \mathrm{C}$, the mixture was loaded onto a $10 \%$ PAGE gel buffered with $0.5 \times$ Tris-borate-EDTA (TBE).

\section{DNase I Footprinting}

The fluorescent FAM-labeled probes were prepared as described above. The DNase I footprinting assays were conducted as published by Wang et al. [35]. For each assay, $400 \mathrm{ng}$ of the probe in at total volume of $40 \mu \mathrm{l}$ was mixed with different amounts of the indicated DNA-binding protein. The preparation of the DNA ladder, 
electrophoresis and data analysis were the same as described before [35], except that the GeneScan-LIZ500 size standard (Applied Biosystems) was used.

\section{Construction of $c a t B_{I}-l a c Z$ and $c a t B_{I I}-$ lacZ Fusions and $\beta$-Galactosidase Activity Assays}

A $309 \mathrm{bp} D N A$ fragment corresponding to the $c a t R_{I}-c a t B_{I}$ intergenic region (from -347 to -39 relative to the $c a t B_{I}$ initiation codon) and a $330 \mathrm{bp}$ DNA fragment corresponding to the $c a t R_{I I}-c a t B_{I I}$ intergenic region (from - 358 to 29 relative to the $c a t B_{I I}$ initiation codon) were amplified by PCR to construct $c a t_{I}$ promoter-lac $Z$ fusion and $c a t_{I I}$ promoter-lacZ fusion, respectively. Two amplified fragments of $c a t_{I}$ and $c a t_{I I}$ promoter were digested with EcoRI and BamHI, respectively, and inserted into $\mathrm{pDN} 19 \mathrm{lac} \Omega$ that had been previously cut with the same enzymes. The resulting plasmids, $\mathrm{pDB}_{\mathrm{I}}$ and $\mathrm{pDB}_{\mathrm{II}}$, were transformed into $E$. coli S17-1 by chemical transformation. The complementation was performed through the conjugation between $E$. coli S17-1 with plasmid $\mathrm{pDB}_{\mathrm{I}}$ and $\mathrm{pDB}_{\mathrm{II}}$ and $P$. putida ND6, $P$. putida ND6- $\Delta c a t R_{I}$, and ND6- $\Delta c a t R_{I I}$. Recombinant $P$. putida was selected on MMB plate containing $0.2 \%$ salicylate $(\mathrm{w} / \mathrm{v} \%)$ with $\mathrm{Cb}, \mathrm{Sp}$ and $\mathrm{Sm}$, and subcultured several times to ensure plasmid stabilization. The $\beta$-galactosidase activity was measured according to the method of Green [31].

\section{Phylogenetic Tree and Analysis of Conserved Sequences}

Database searches were performed using BLAST at the National Center for Biotechnology Information (NCBI) website. Multiple sequence alignments were performed using Clustal W. Then, a neighbor-joining (NJ) phylogenetic tree was constructed using MEGA software version 5.0, and the branching reliability was tested using bootstrap re-sampling (1,000 pseudo-replicates). Analysis of conserved motifs based on known sequences was conducted using WebLogo to generate LOGO diagrams.

\section{Results}

\section{Functional Analysis of the Two Catechol-Degrading Gene Clusters}

As mentioned above, the genome of $P$. putida ND6 encodes two catechol-degrading gene clusters $\left(c a t R_{I} B_{I} C_{I} A_{I}\right.$ and cat $R_{I I} B_{I I} C_{I I} A_{I I}$ ) (Fig. 1). To investigate the possible physiological role of these two orthologous clusters, cat $A$ (encoding $\mathrm{C} 12 \mathrm{O}$ ) and $n a h H$ (encoding $\mathrm{C} 23 \mathrm{O}$ ) from the large plasmid pND6-1, which are responsible for catechol ring cleavage [16], were knocked out. The obtained double-mutant strain ND6- $\Delta$ catAnahH was still able to grow on naphthalene by employing the catechol-degrading gene clusters in the genome as a backup, although the $\mathrm{C} 12 \mathrm{O}$ activity dropped from 74.60 to $43.02 \mathrm{U} / \mathrm{mg}$ (Fig. 2). Furthermore, to examine the relative roles of the cat $_{I}$ and $c a t_{I I}$ clusters in catechol metabolism, we disrupted the $c a t R_{I}$ and $c a t R_{I I}$ regulatory genes and examined the properties of the resulting strains. The ability of these strains to use naphthalene as the sole carbon source was tested in growth and degradation experiments. Interestingly, inactivation of $c a t R_{I}$ or $c a t R_{I I}$ had no obvious effect on the strains' ability to utilize naphthalene (Fig. 3).

\section{Transcriptional Analysis of the Two Catechol-Degrading Gene Clusters}

The cDNA of $P$. putida ND6 was used as template to amplify the intergenic regions of the $c a t B_{I} C_{I} A_{I}$ and $c a t B_{I I} C_{I I} A_{I I}$ operons. The results indicated that either the $c a t B_{I} C_{I} A_{I}$ or $c a t B_{I I} C_{I I} A_{I I}$ cluster can be co-transcribed

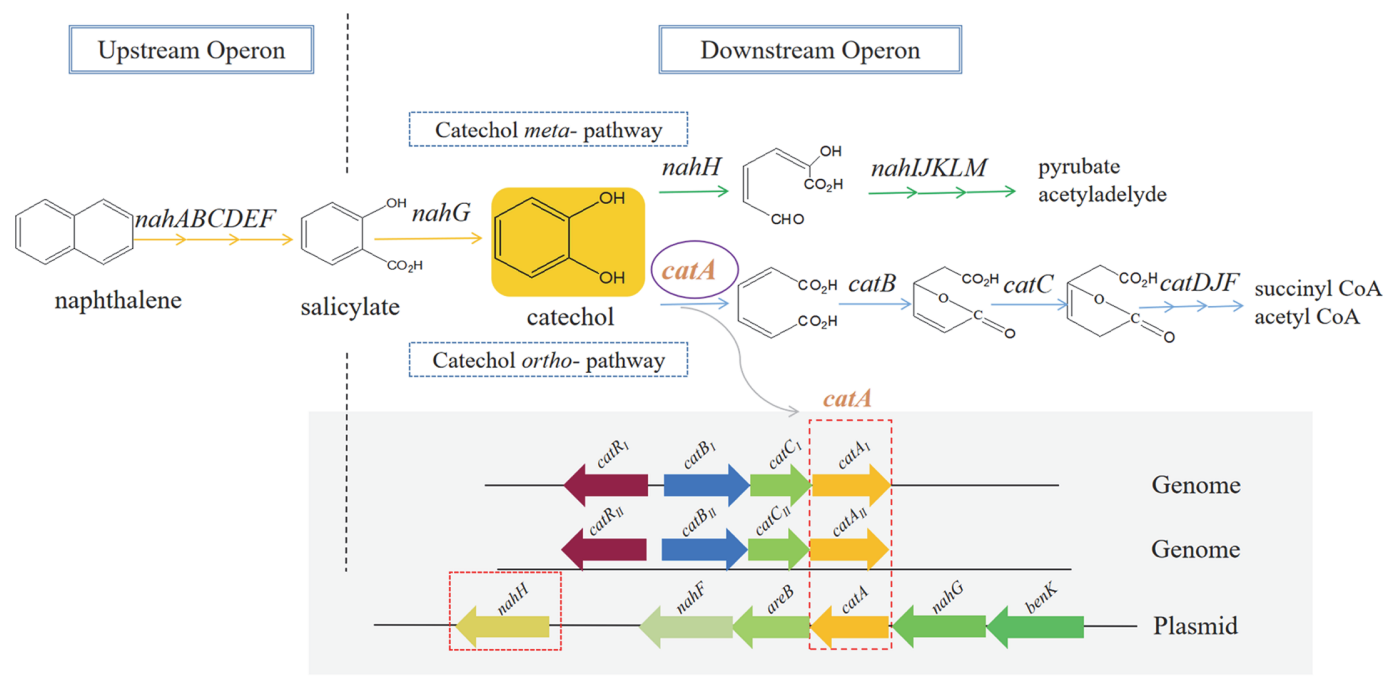

Fig. 1. Genetic, regulatory and biochemical connections of naphthalene catabolism in P. putida ND6. The figure sketches the pathways involved in the naphthalene catabolism of $P$. putida ND6: the upstream operon (nahABCDEF) for the conversion of naphthalene into salicylate; the downstream operon for the conversion of salicylate into catechol and eventually into intermediates of the central carbon metabolism. Catechol metabolism can proceed via either the ortho- or the meta-cleavage pathway. Both pathways converge towards catechol and diverge at that point, as this compound can be cleaved between positions 1 and 2 by cat $A$, whereas nahH cleaves between positions 2 and 3 . The three cat $A$ genes are located on the chromosome and large plasmid, respectively. 


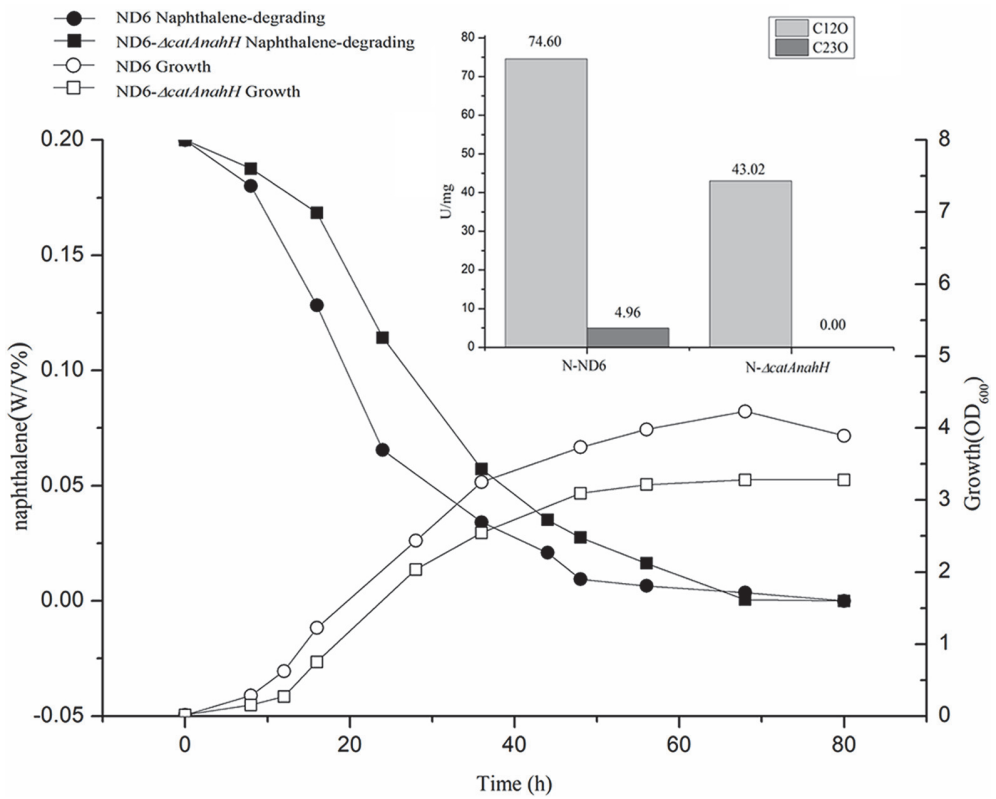

Fig. 2. Naphthalene-degradation phenotype and catechol dioxygenase enzyme activities of $P$. putida ND6 and the ND6- $\Delta$ catAnahH mutant. Naphthalene $(0.2 \%$, w/v \%) was provided as the sole carbon source. The small figure shows the $\mathrm{C} 12 \mathrm{O}$ and $\mathrm{C} 23 \mathrm{O}$ enzyme activity of $P$. putida ND6 and ND6- $\Delta$ cat AnahH.

(Fig. 4). However, the results of RT-qPCR revealed that the transcription of the downstream genes $c a t C_{I}$ and $c a t A_{I}$ was higher than that of $c a t B_{I}$ (Fig. $5 \mathrm{~A}$ ), suggesting that $c a t C_{I}$ and $c a t A_{I}$ were independently transcribed, while the cat $B_{I} C_{I} A_{I}$ cluster was co-transcribed. A similar phenomenon was also observed in the cluster cat $B_{I I} C_{I I} A_{I I}$ (Fig. 5A).

In the naphthalene medium, the activity of transcription (Fig. 5A) and expression levels (Fig. 2, small figure) of three cat $A$ genes and $\mathrm{C} 12 \mathrm{O}$ were much higher than $n a h H$ gene and $\mathrm{C} 23 \mathrm{O}$. Therefore, the naphthalene metabolism of $P$. putida ND6 proceeds via catechol cleavage in both the ortho and meta positions, whereby the ortho-cleavage pathway is the main cleavage pathway. The transcriptional levels of the ortho-cleavage pathways $\left(\operatorname{cat}_{I}, \operatorname{cat}_{I} \operatorname{cat} C_{I}\right.$, cat $_{I I}$, cat $_{I I}$, cat $_{I I}$, catA) were all increased in naphthalene medium, while that of meta-cleavage pathways $(n a h H)$ was not (Fig. 5A). It indicates that the ortho-cleavage pathways can be induced by naphthalene or its metabolites but the meta-cleavage pathway apparently cannot. Furthermore, we measured the transcriptional levels of $c a t_{I}$ and $c a t_{I I}$ in the mutant strains ND6- $\Delta c a t R_{I}$ and ND6- $\Delta c a t R_{I I}$, following cultivation in the presence of glucose or naphthalene. For the ND6- $\Delta c a t R_{I}$ strain (only cat $R_{I I}$ is functional), the transcriptional levels of $c a t B_{I}$ were significantly decreased, while the $\operatorname{cat} B_{I I}$ gene cluster could still be induced (Fig. $5 \mathrm{~B}$ ). For the ND6- $\Delta c a t R_{I I}$

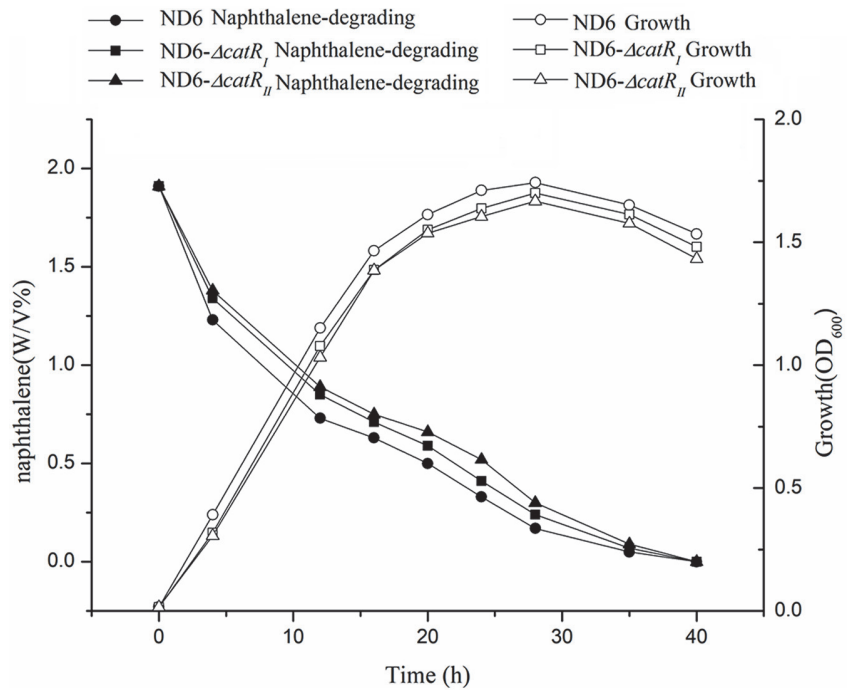

Fig. 3. Growth and naphthalene-degradation curves of $P$. putida ND6 wild type, as well as the mutants ND6$\Delta \boldsymbol{c a t} R_{I}$ and ND6- $\Delta \boldsymbol{c a t} R_{I I}$. Naphthalene $(0.2 \%, \mathrm{w} / \mathrm{v})$ was provided as the sole carbon source. 


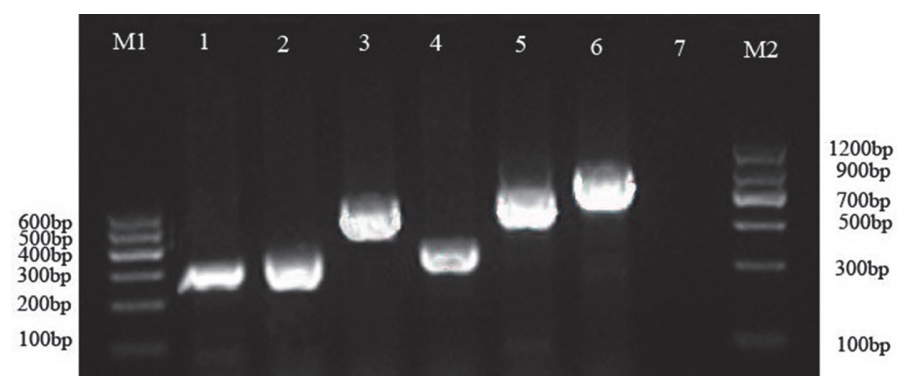

Fig. 4. Agarose gel plots were used to determine the transcription patterns of the two cat gene clusters. M1: Tiangen DNA Marker I; M2: Tiangen DNA Marker II; Lane1: Band of the $\operatorname{cat} B_{I^{-}}$cat $C_{I}$ intergenic region DNA fragment; Lane 2: Band of the $c a t C_{I}-c a t A_{I}$ intergenic region DNA fragment; Lane 3: Band of the $c a t B_{I}-c a t A_{I}$ intergenic region DNA fragment; Lane 4: Band of the $c a t B_{I I}-c a t C_{I I}$ intergenic region DNA fragment; Lane 5: Band of the $c a t C_{I I}-c a t A_{I I}$ intergenic region DNA fragment; Lane 6: Band of the $\operatorname{cat}_{I I}-{ }^{-} a t A_{I I}$ intergenic region DNA fragment; Lane 7: negative control.

strain (only $c a t R_{I}$ is functional), the transcriptional level of $c a t B_{I I}$ was also decreased while the $c a t B_{I}$ gene cluster could still be induced (Fig. $5 \mathrm{C}$ ). This result demonstrated that Cat $\mathrm{R}_{\mathrm{I}}$ and $\mathrm{Cat} \mathrm{R}_{\mathrm{II}}$ are the native regulatory proteins of the $c a t_{I}$ cluster and the $c a t_{I I}$ cluster, respectively.

To investigate their possible regulatory roles, the impacts of $c a t R_{I}$ and $c a t R_{I I}$ were further analyzed by determining the transcriptional levels of all six catechol-degradation genes in wild-type ND6 and the mutants when grown with naphthalene as the sole carbon source. When either cat $R_{I}$ or $c a t R_{I I}$ was knocked out, the transcription of the $c a t_{I}$ or $c a t_{I I}$ cluster could still be detected (Fig. $5 \mathrm{D}$ ). It indicates that Cat $\mathrm{R}_{\mathrm{I}}$ and $\mathrm{CatR}_{\mathrm{II}}$ might

A

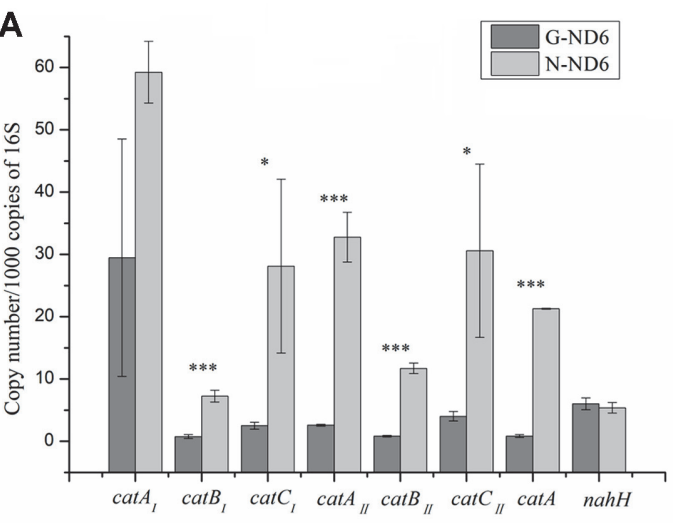

Gene

C

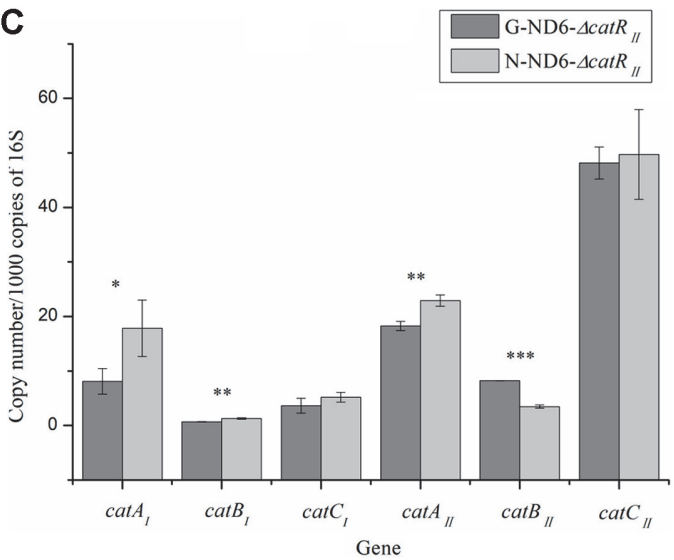

B

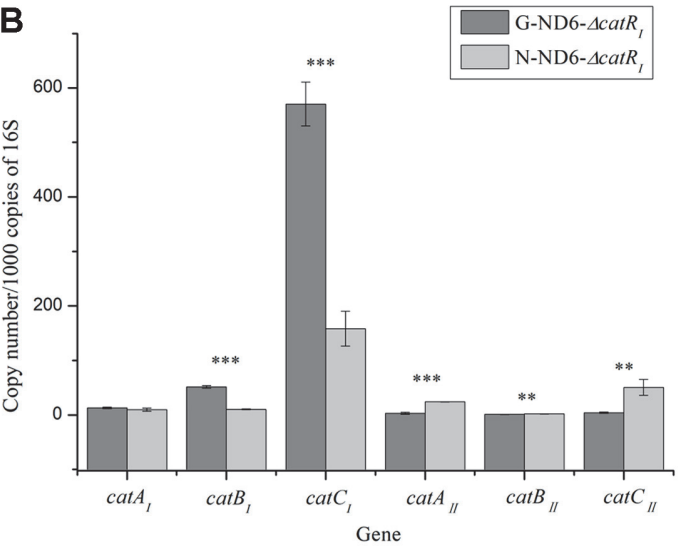

D

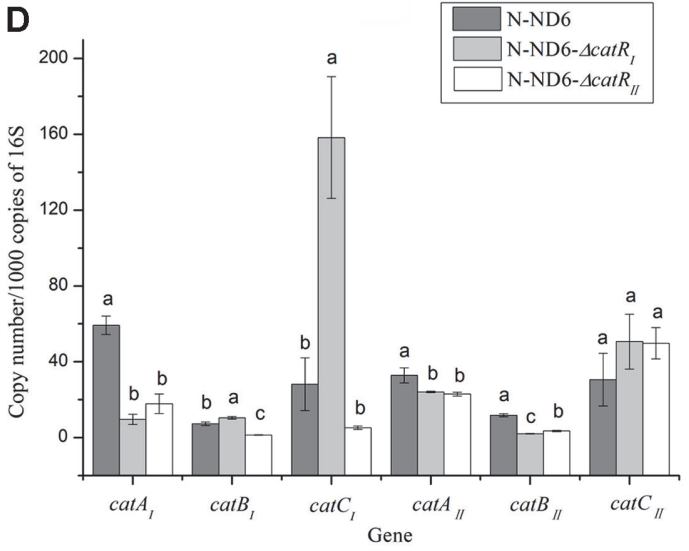

Fig. 5. Copy number determination by absolute RT-qPCT using plasmid standards. Transcript copy number of genes per 1000 mRNA transcript copies of the $16 \mathrm{~S}$ rRNA in ND6 (A), ND6- $\Delta$ cat $R_{I}(\mathbf{B})$, and ND6- $\Delta$ cat $R_{I I}(\mathbf{C}) .{ }^{*} p<0.05,{ }^{* *} p<$ $0.01{ }^{* * *} p<0.001$ between cells grown on naphthalene and on glucose. (D) Transcript copy number of two cat gene clusters per 1000 mRNA transcript copies of the $16 \mathrm{~S}$ rRNA in ND6, ND6- $\Delta c a t R_{I}$ and ND6- $\Delta c a t R_{I I}$. Different superscript letters indicate statistically significant differences among experimental groups ( $p<0.05$; Duncan's multiple range test). Either naphthalene (N-) or glucose (G-) was provided as the sole carbon source. Bars show the standard errors of the means. 


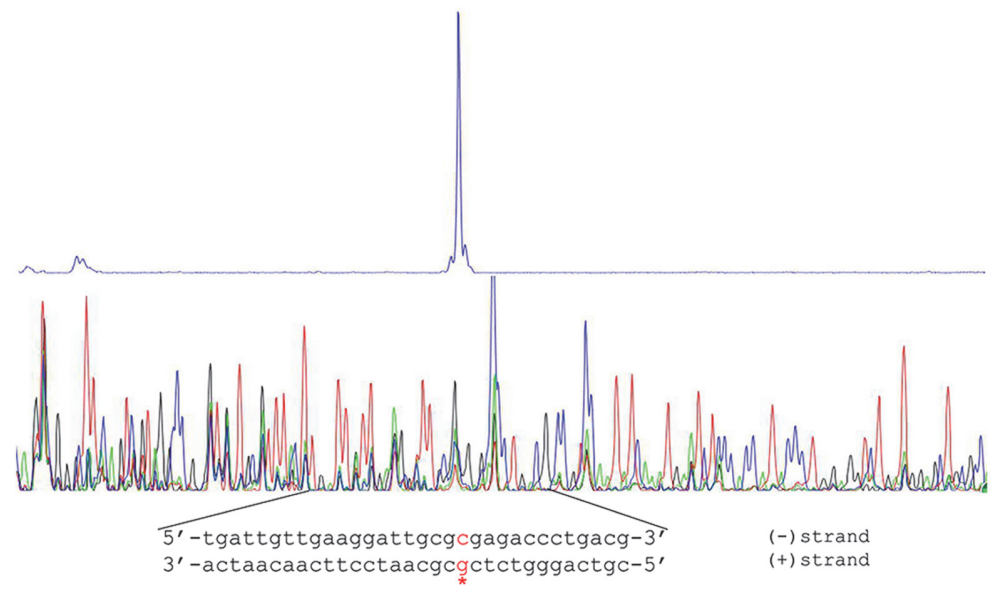

Fig. 6. Results of the primer-extension assay. Characterization of the cat $_{1}$ transcription start site (TTS) using the primer extension assay. The primer extension experiments used the primer cat $\mathrm{B}_{\mathrm{I}}$-pe (Table 2), which was designed to bind downstream of the cat $_{I}$ initiation codon. Comparison of the sequencing results of the cDNA (above) and the genomic DNA (below) to determine the TSS (marked with a red asterisk).

cross-regulate the transcription of each other's target genes, and explains that the naphthalene degradation curves of ND6- $\Delta c a t R_{I}$ and ND6- $\Delta c a t R_{I I}$ did not exhibit significant changes (Fig. 3).

Promoter Structure of the Two Catechol-Degrading Gene Clusters

The primer-extension assay indicated that the transcription start site (TSS) of $c_{a} t_{I}$ is located at a G nucleotide (Fig. 6). Surprisingly, the primer extension assay of $c_{\text {II }}$ failed three times based on reliable methods, probably because the transcript abundance of the $\mathrm{cat}_{I I}$ cluster is particularly low.

The Cat $R_{I}$ and Cat $R_{I I}$ binding regions were also studied using DNase I footprinting (Fig. 7). Purified Cat $R_{I}$ was
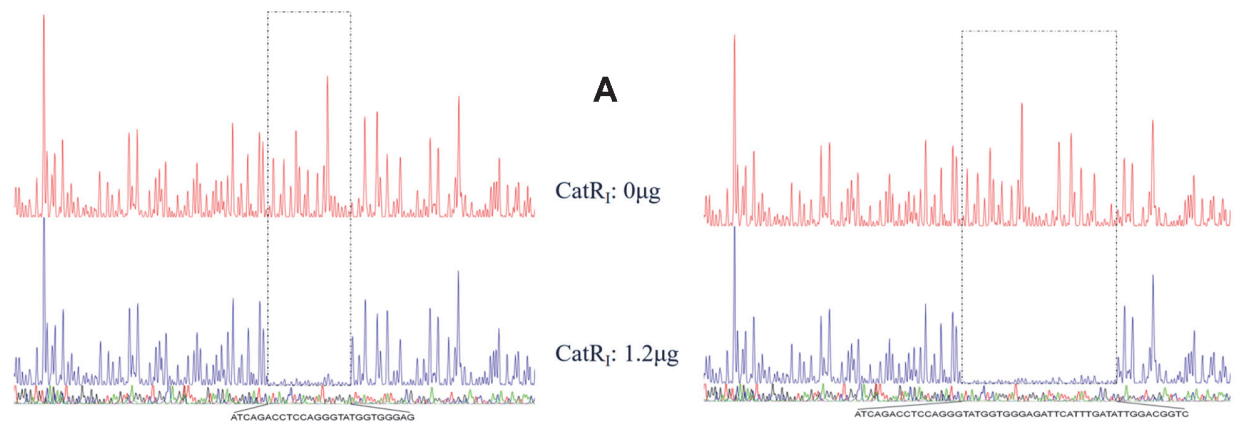

B
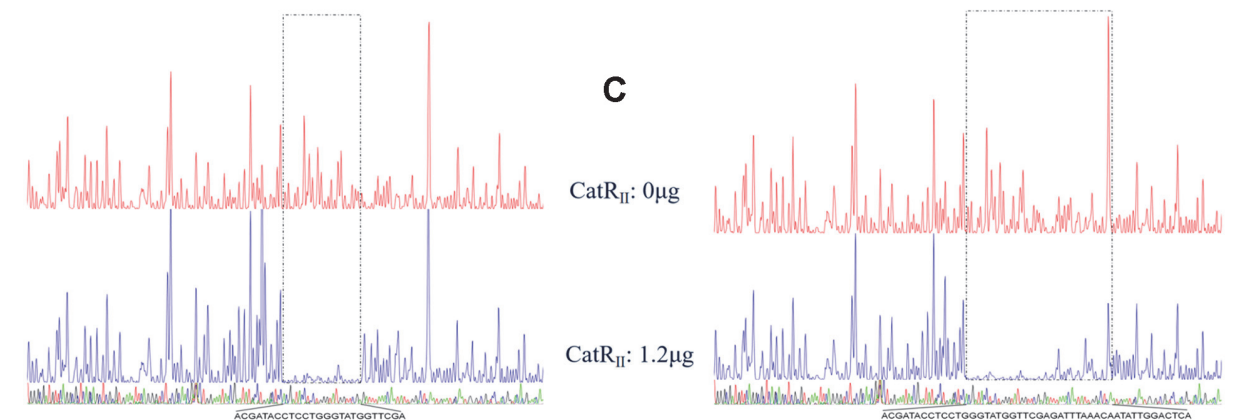

CatR $: 0 \mu \mathrm{g}$ CCM: $1 \mu \mathrm{M}$

CatR $: 1.2 \mu \mathrm{g}$ CCM: $1 \mu \mathrm{M}$

D

$\mathrm{CatR}_{\mathrm{II}}: 0 \mu \mathrm{g}$ CCM: $1 \mu \mathrm{M}$

Fig. 7. DNase I footprinting analysis of $\operatorname{CatR}_{\mathrm{I}}(\mathrm{A}, \mathrm{B})$ binding to the $\operatorname{cat} B_{I}$ promoter and $\mathrm{Cat}_{\mathrm{II}}(\mathrm{C}, \mathrm{D})$ binding to the cat $_{\text {II }}$ promoter with or without CCM. Based on these results and earlier reports on bacterial promoter prediction [39], we identified the promoter structure of the two catechol-degrading gene clusters (Fig. 8). The putative TSS of cat $_{I}$ was consistent with the primer-extension experiment, and the putative TSS of cat $_{I I}$ was located $67 \mathrm{bp}$ upstream of the $c a t B_{I I}$ initiation codon. Other motifs of the $c a t_{I}$ and $c a t_{I I}$ promoters were identified by comparing to the reported conserved sequences recognized by RNA polymerase $[11,13,19,23,40,41]$, including the -35 element (positions -35 to -30 , if the transcriptional start site is denoted as +1 ), the -10 element (positions -12 to -7 ) and the discriminator element (Dis; -6 to -4 ) (Fig. 8). 


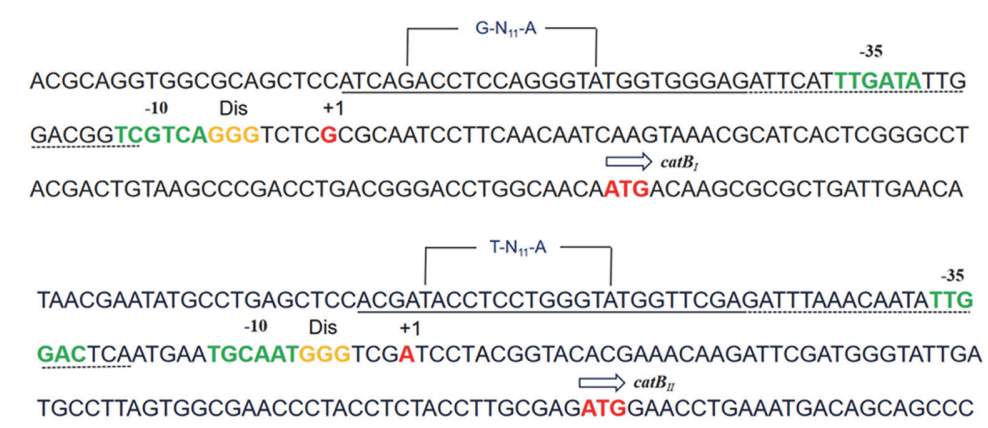

A

GACGGTCGTCAGGGTCTCGCGCAATCCTTCAACAATCAAGTAAACGCATCACTCGGGCCT

ACGACTGTAAGCCCGACCTGACGGGACCTGGCAACAATGACAAGCGCGCTGATTGAACA

B

Fig. 8. Structure of the $c \boldsymbol{c a t} B_{I}$ and $\boldsymbol{c a t} \boldsymbol{B}_{I I}$ promoter regions. (A) The promoter region of the cat $_{I}$ gene cluster. (B) The promoter region of the $c a t_{I I}$ gene cluster. The transcription start site is shown as +1 . The predicted discriminator element (Dis), initiation codon (arrows, the direction represents the direction of transcription), and -10 and - 35 regions of the promoter were also designated above the sequence. The promoter regions of $c a t_{I}$ and $c a t_{I I}$ protected by Cat $\mathrm{R}_{\mathrm{I}}$ or Cat $\mathrm{R}_{\mathrm{II}}$ from DNase I digestion without CCM, called the repression binding site (RBS), are marked with black solid lines; the extended protected region in the presence of CCM, called the activation binding site (ABS), is marked with the black dotted line.

incubated with a $408 \mathrm{bp}$ fragment labeled with FAM, with a sequence corresponding to the promoter region of $c a t_{I}$, and the resulting complexes were treated with DNase I, followed by DNA fragment analysis by capillary electrophoresis. The binding sequence of the $\mathrm{CatR}_{\mathrm{II}}-$ cat $_{\mathrm{II}}$ complex was assessed using the same method, and a 403 bp FAM-labeled DNA fragment was incubated with purified Cat $\mathrm{R}_{\mathrm{II}}$. In the absence of CCM, Cat $\mathrm{R}_{\mathrm{I}}$ protected a continuous $26 \mathrm{bp}$ region that had also been determined to be located from - 137 to -112 relative to the cat $B_{I}$ codon (Fig. $7 \mathrm{~A}$ ). Cat $\mathrm{R}_{\text {II }}$ protected a continuous $25 \mathrm{bp}$ region that had also been determined to be located from -137 to -113 relative to the $\mathrm{cat}_{\mathrm{I}}$ initiation codon (Fig. 7C). In the presence of CCM, CatR $\mathrm{I}_{\mathrm{I}}$ protected a continuous $48 \mathrm{bp}$ region that was determined to be located from -137 to -90 relative to the cat $B_{I}$ initiation codon (Fig. $7 \mathrm{~B}$ ). CatR $\mathrm{R}_{\mathrm{II}}$ protected a continuous $41 \mathrm{bp}$ region that was determined to be located from - 137 to -97 relative to the $c a t B_{I}$ initiation codon (Fig. 7D). These results demonstrated that CCM has a significant effect on the DNA binding mode of CatR. In the absence of CCM, CatR bound the repression binding site (RBS), which might be associated with the negative regulation of itself. In the presence of CCM, CatR occupied an adjacent downstream site (Fig. 8), designated as the activation binding site (ABS) $[36,37]$. Like most LysR proteins, the DNA-binding sites of CatR $_{I}$ and CatR $\mathrm{R}_{\mathrm{II}}$ invariably contain incomplete inverted repeats $\left(\mathrm{G}-\mathrm{N}_{11}-\mathrm{A}\right)$ or inverted repeats $\left(\mathrm{T}-\mathrm{N}_{11}-\mathrm{A}\right)$, respectively [38]. The results also indicated that the -35 and -10 regions of the cat promoter were important for promoter activity but not for CatR binding.

\section{Transcriptional Cross-Regulation between the Two Catechol-Degrading Gene Clusters}

The regulatory proteins $\mathrm{Cat}_{\mathrm{I}}$ and $\mathrm{Cat}_{\mathrm{II}}$ were cloned into a vector to introduce six histidine residues at the $\mathrm{C}$ terminus of the protein, and were expressed and purified from E. coli as described in the Materials and Methods section. The binding abilities of Cat $\mathrm{R}_{\mathrm{I}}$ and $\mathrm{CatR}_{\mathrm{II}}$ to the upstream regulatory regions of $c a t_{I}$ and $c a t_{I I}$ were studied

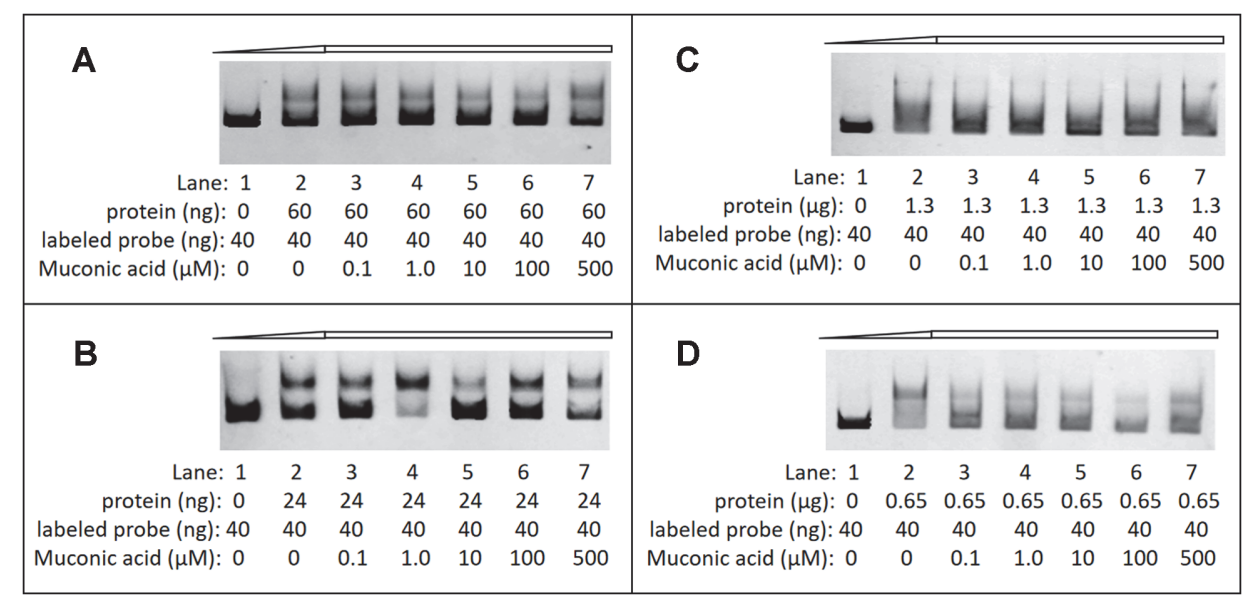

Fig. 9. EMSA of Cat $\mathrm{R}_{\mathrm{I}}$ and $\mathrm{CatR}_{\mathrm{II}}$ binding to the $\boldsymbol{c a t}_{I}$ and cat $_{I I}$ promoters, respectively. (A) EMSA of Cat $\mathrm{R}_{\mathrm{I}}$ binding to the cat $_{I}$ promoter. (B) EMSA of CatR $\mathrm{III}_{\mathrm{II}}$ binding to the $\mathrm{cat}_{\text {II }}$ promoter. (C) EMSA of CatR $\mathrm{R}_{\mathrm{I}}$ binding to the $\mathrm{cat}_{I I}$ promoter. (D) EMSA of CatR $\mathrm{R}_{\mathrm{II}}$ binding to the $\mathrm{cat}_{\mathrm{I}}$ promoter. The first lane contains the free fragment, lanes 2-7 contain labeled probe and Cat $\mathrm{R}_{\mathrm{I}}$ or $\mathrm{CatR}_{\text {II }}$ protein, with $0,0.1,1.0,10,100$, and $500 \mu \mathrm{M}$ muconic acid, respectively. The concentration of the labeled probe was fixed at $40 \mathrm{ng}$. 
by EMSA using a concentration gradient of CCM (Fig. 9). As expected, the addition of $60 \mathrm{ng} \mathrm{CatR}_{\mathrm{I}}$ to $40 \mathrm{ng}$ of the labeled probe caused a strong shift in the mobility of the $c a t_{I}$ promoter fragment (Fig. 9A). Notably, CatR ${ }_{I}$ could also strongly bind to the $c a t_{I I}$ promoter region (Fig. 9C). By contrast, Cat $\mathrm{R}_{\mathrm{II}}$ was able to specifically bind the cat II and $c a t_{I}$ promoter regions, but the binding stability of the CatR $\mathrm{R}_{\mathrm{II}}-c a t_{I I}$ and $\mathrm{CatR}_{\mathrm{II}}-c a t_{I}$ complexes was obviously reduced (Figs. 9B and 9D). These results support the hypothesis that Cat $R_{I}$ and $C a t R_{I}$ might cross-regulate the transcription of each other's target genes. In addition, CCM did not affect the binding of Cat $\mathrm{R}_{\mathrm{I}}$ to the corresponding target regions, which was in agreement with previous reports $[10,13]$. However, the binding regions in the presence and absence of CCM might be different. As can be seen in Figs. 9B and 9D, adding CCM to the reaction mixture decreased the intensity of the DNA band, indicating that Cat $\mathrm{R}_{\mathrm{II}}$ recognizes and binds to the $c a t_{I I}$ and $c a t_{I}$ promoters when CCM is at a lower concentration.

Promoter Activity Analysis of the Two Catechol-Degrading Gene Clusters

The primer extension assay indicated that there might be significant differences in the abundance of transcripts between the $c a t_{I}$ and $c a t_{I I}$ clusters. To test this idea, the promoter activities of $c a t_{I}$ and $c a t_{I I}$ (transcriptionally fused to the lacZ gene in $\mathrm{pDN} 19 \mathrm{lac} \Omega$ ) were examined using the classical reporter $\beta$-galactosidase (Table 3 ).

As expected, in strain NP2 (ND6 wild type containing the $c a t_{I I}$ promoter-lacZ fusion), the $\beta$-galactosidase activity was low in both glucose and naphthalene media. By contrast, the $\beta$-galactosidase activity of strain NP1 (ND6 wild type containing the $c a t_{I}$ promoter-lacZ fusion) was very high, indicating that the cat $_{I}$ promoter is much stronger than the $c a t_{I I}$ promoter. The activity of the $c a t_{I I}$ promoter in cells grown on glucose or naphthalene showed little variation, probably because the transcript abundance was too low. The $\beta$-galactosidase activity of NP1 cells grown on glucose was approximately $75.9 \%$ of the activity of cells grown on naphthalene, indicating that naphthalene or its metabolites can slightly induce the cat $_{I}$ promoter but are not necessary for its activity.

To confirm the function of $\mathrm{CatR}_{\mathrm{I}}$, we introduced the plasmid $\mathrm{pDB}_{\mathrm{I}}\left(\mathrm{pDN} 19 \mathrm{lac} \Omega+\right.$ cat $_{I}$ promoter $)$ and plasmid $\mathrm{pDB}_{\mathrm{II}}\left(\mathrm{pDN} 19 \mathrm{lac} \Omega+c a t_{I I}\right.$ promoter) into ND6- $\Delta c a t R_{I}$ and ND6- $\Delta c a t R_{I I}$, respectively, resulting in the strains ND1P1 and ND1P2. A drastic reduction of $\beta$-galactosidase activity was observed in ND1P1, whereby the promoter activity of $c a t_{I}$ was almost equal to that of the control strain NC (ND6 containing pDN19lac $\Omega$ ) in glucose-grown cells, but the cat $_{I}$ promoter could be still induced slightly in naphthalene-grown cells. This result suggested $\mathrm{CatR}_{\mathrm{II}}$ might function as a backup regulator. Interestingly, the promoter activity of cat ${ }_{I I}$ was also decreased in the CatR $R_{I}$ mutant (ND1P2) compared with NP2, suggesting that Cat $R_{I}$ might competitively bind the promoter region of $c a t_{I I}$ and initiate transcription more effectively in the wild-type ND6. On the other hand, we found that the $\beta$-galactosidase activity of ND2P1 (ND6- $\Delta c a t R_{I I}$ containing $\mathrm{pDN} 19 \mathrm{lac} \Omega+$ cat $_{I}$ promoter) was obviously higher than that of NP1, both on glucose and on naphthalene. This result suggested that Cat $\mathrm{R}_{\mathrm{I}}$ could bind the $c a t_{I I}$ promoter and initiate transcription more efficiently with or without the inducer when Cat $\mathrm{R}_{\mathrm{II}}$ is unavailable. All these results were in agreement with the EMSA results. Through in vitro and in vivo experiments, we have confirmed that two regulatory proteins Cat $\mathrm{R}_{\mathrm{I}}$ and $\mathrm{CatR}_{\mathrm{II}}$ have interactive regulation on the cat $_{I}$ and $c a t_{I I}$ gene clusters, and Cat $R_{I}$ has a stronger regulatory and activation effect on the gene clusters than Cat $R_{I I}$.

\section{Evolutionary Analysis of the Two Catechol-Degrading Gene Clusters and Their Promoter Regions}

To analyze the diversity of the two catechol-degrading gene clusters in the ND6 genome, 24 sequences of different cat gene clusters were downloaded from NCBI to construct a phylogenetic tree (Fig. 10). Overall, the phylogenetic analysis showed that the cat gene clusters have significant phylogenetic diversity, and could be divided into two main groups depending on the genus. Most Pseudomonas spp. have two cat clusters, which constituted one group, including $\mathrm{cat}_{I}$ and $c a t_{I I}$ of the ND6 strain. In the Pseudomonas spp. group, most second copies of the cat gene clusters, including $\operatorname{cat} R_{I I} B_{I I} C_{I I} A_{I I}$ of $P$. putida ND6, formed a monophyletic clade. By contrast, most $c a t_{1}$ gene clusters, including $c a t R_{I} B_{I} C_{I} A_{I}$ of $P$. putida ND6, formed a separate clade, indicating that $c a t_{I}$ and $\mathrm{cat}_{I I}$ of ND6 have different evolutionary origins. Interestingly, in three Burkholderia sp. strains (GenBank: CP001052.1, GenBank: AB035483.1 and GenBank: CP026112.1), catA was found to be transcribed individually while catR-catB-catC was transcribed in the opposite direction, which is different from the common order catBcat $C /$ cat $A$-cat $A /$ cat $C$. Therefore, the expression of $\mathrm{C} 12 \mathrm{O}$, encoded by cat $A$, must be very adaptable to respond to the environment. However, gene clusters with different transcription sequences have a far-reaching relationship. Consistent with a previous study [38], analysis of an alignment of nine intergenic regions of $c a t B$ downloaded from NCBI confirmed the presence of two types of binding motifs, with conserved sequences $\mathrm{T}-\mathrm{N}_{11}-\mathrm{A}$ and mutant sequences $\mathrm{G}-\mathrm{N}_{11}-\mathrm{A}$ (Fig. 11). In agreement with a report by Parsek et al. [37], the mutation of a $\mathrm{T}$ to a $\mathrm{G}$ resulted in an increase in the binding of CatR $\mathrm{I}_{\mathrm{I}}$ to both the $c a t B_{I}$ and $c a t B_{I I}$ promoters (Fig. 9).

Table 3. Determination of relative promoter activities via $\beta$-galactosidase expression (measured in Miller units).

\begin{tabular}{lccccccc}
\hline \multicolumn{1}{c}{ Strains } & NC & NP1 & NP2 & ND1P1 & ND1P2 & ND2P1 & ND2P2 \\
\hline MMB + glucose & 8.37 & 151.30 & 15.89 & 8.09 & 9.45 & 196.37 & 8.19 \\
MMB + naphthalene & 8.30 & 199.31 & 11.52 & 11.87 & 9.94 & 297.38 & 11.54
\end{tabular}

${ }^{*}$ The $\beta$-galactosidase activity was determined in the following strains: NC (ND6 containing pDN19lac $\Omega$ ); NP1 (ND6 containing pDN19lac $\Omega+$ cat $_{I}$ promoter); NP2 (ND6 containing pDN19lac $\Omega+$ cat $_{I I}$ promoter); ND1P1 (ND6- $\Delta$ cat $R_{I}$ containing $\mathrm{pDN} 19$ lac $\Omega+$ cat $_{I}$ promoter); ND1P2 (ND6- $\Delta$ cat $R_{I}$ containing pDN19lac $\Omega+$ cat $_{I I}$ promoter); ND2P1 (ND6- $\Delta$ cat $R_{I I}$ containing $\mathrm{pDN} 19$ lac $\Omega+$ cat $_{I}$ promoter $)$ ND2P2 (ND6- $\Delta$ cat $R_{I I}$ containing $\mathrm{pDN} 19$ lac $\Omega+$ cat $_{\text {II }}$ promoter $)$ 


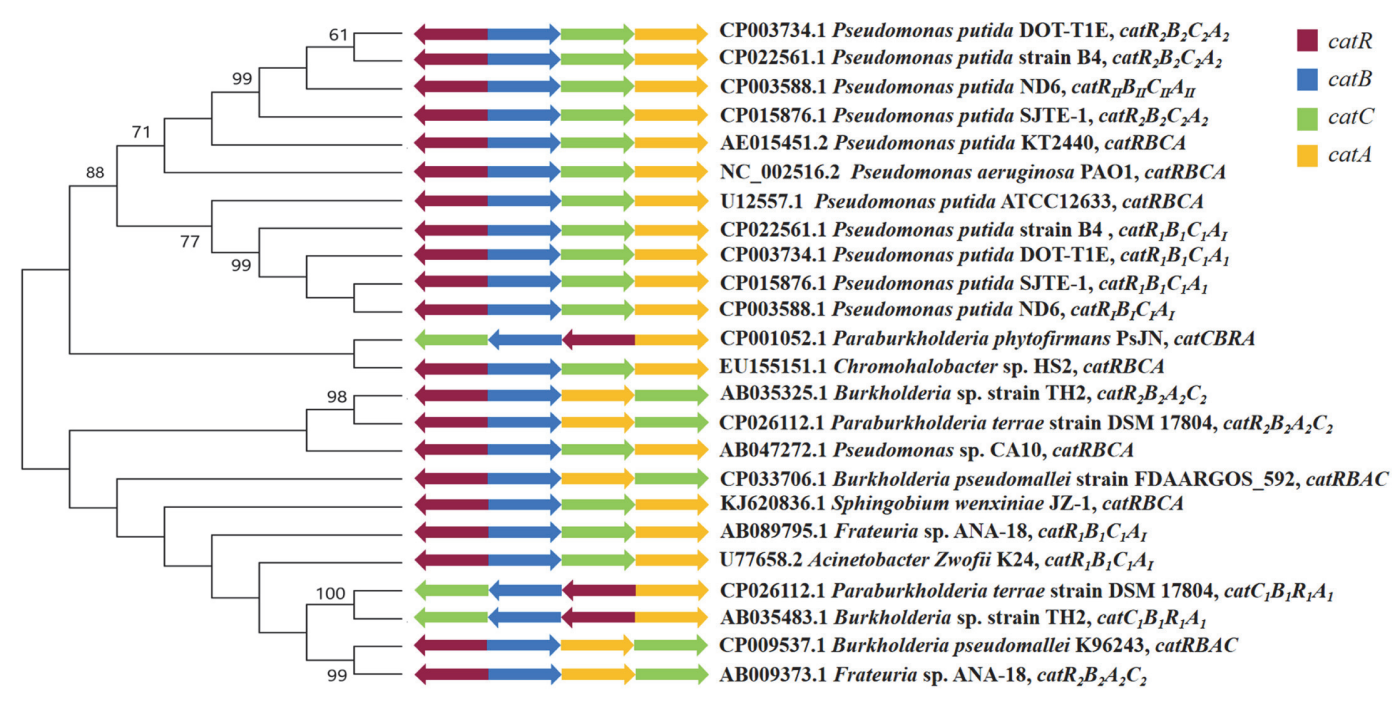

Fig. 10. Phylogenetic analysis of cat gene clusters. The phylogenetic tree was generated using MEGA 5.0 with maximum parsimony and 1000 bootstrap replicates. Reference DNA sequences were selected by BLAST searches in the NCBI database.

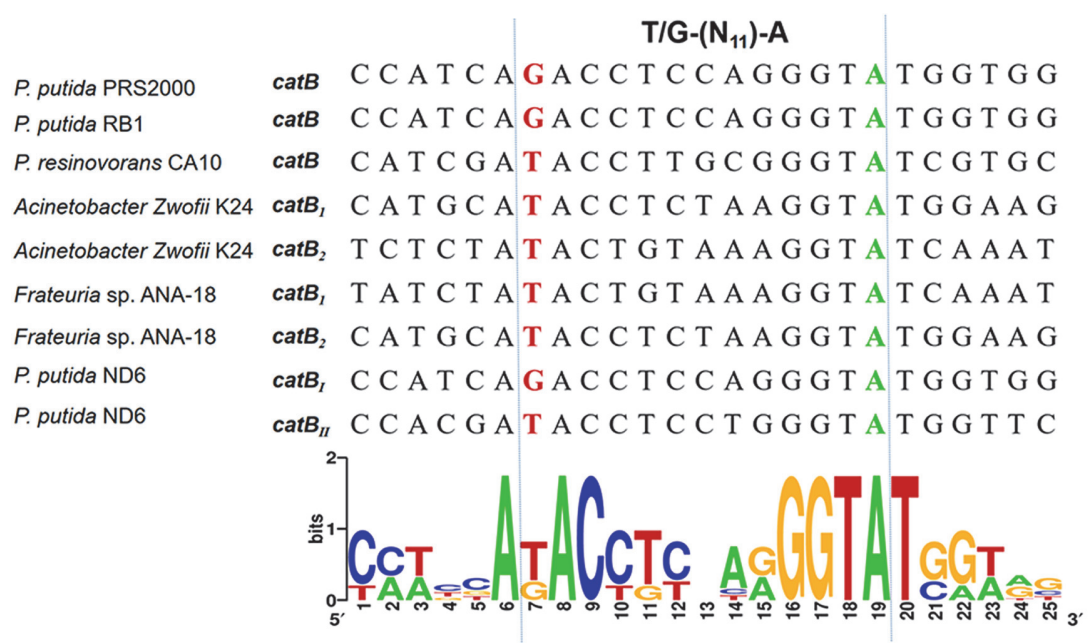

Fig. 11. LOGO diagrams of the binding sites occupied by CatR. The sequence was derived from the $c a t R-B$ intergenic region of the reported catRBCA gene clusters, including P. putida PRS2000 [13], P. putida RB1 [11], Pseudomonas resinovorans strain CA10 [40], Acinetobacter lwoffii K24 [41], Frateuria sp. ANA-18 [19, 23], and P. putida ND6. The LOGO diagrams were built using all the predicted binding sites for the respective Cat $\mathrm{R}$ in all studied genomes in all cat $R-B$ intergenic regions. The sequence between the two dashed lines is an inverted repeat $\left(T-\mathrm{N}_{11}-\mathrm{A}\right)$ or an incomplete inverted repeat $\left(\mathrm{G}-\mathrm{N}_{11}-\mathrm{A}\right)$. The T/G and $\mathrm{A}$ residues of the $\mathrm{T} / \mathrm{G}-\mathrm{N}_{11}-\mathrm{A}$ motif were marked in red and green, respectively.

\section{Discussion}

A number of aerobic biodegradation pathways of aromatic compounds like phenol, benzoate, or naphthalene converge into catechol ring cleavage [42]. Our previous study showed that each C12O isozyme in P. putida ND6, encoded by the separate cat $A$ genes on the chromosome and the large pND6-1 plasmid, belonged to independent branches of the phylogenetic tree and have different enzymatic properties [17]. The two cat $A$ genes located on the chromosome (Fig. 1) were found to significantly contribute to the fitness of the host strain that is adapted to high concentrations of naphthalene [27]. The phenotypic determination showed that the growth curve of P. putida ND6- $\Delta$ catAnahH decreased slightly compared to the wild type, indicating that the two catechol ortho-cleavage clusters in the genome play an important role but are not the only genes with this function. In nature, many bacteria grow and develop by catechol ortho- and meta-cleavage pathways to adapt to the presence of aromatics in the environment $[3,43]$. The results of RT-qPCR and the catechol dioxygenase enzyme activity assay supported this idea. In addition to P. putida ND6, many other strains, especially of Pseudomonas and Burkholderia spp., possess multiple cat gene clusters. In Burkholderia sp. strain TH2, although $c a t A_{2}$ is not indispensable for the 
growth on $2 \mathrm{CB}$, the presence of the $\mathrm{cat}_{2}$ gene cluster is beneficial [44]. Similar observations were made in Acinetobacter lwoffii K24, and Frateuria species ANA-18 [19]. Thus, the presence of multiple cat genes or clusters in the same cell is a widespread phenomenon[14] that may help the host adapt to changing environments by either reducing the intracellular concentration of catechol, which is a toxic intermediate of the degradation of various aromatic compounds, or by substituting for each other to circumvent harmful mutations [3].

It is interesting to note the different arrangement of cat genes in Fig. 10. Most of them are arranged in the order cat $B$-cat $C /$ cat $A$-cat $A / c a t C$, while the catR gene is divergently transcribed from the operon. Furthermore, the cat $A$ gene is transcribed separately from catR-catB-catC as arranged in Paraburkholderia terrae strain DSM 17804, Burkholderia sp. strain TH2 and Paraburkholderia phytofirmans strain PsJN. At the same time, we found that catA is under independent transcriptional regulation in the ND6 strain, while the catBCA operon is co-transcribed. Consequently, we assumed that individual transcription of the cat $A$ gene might be important and not an accidental evolutionary event. Notably, catA encodes the rate-limited enzyme $\mathrm{C} 12 \mathrm{O}$ in the catechol orthocleavage pathway, so the abundance of $\mathrm{C} 12 \mathrm{O}$ should be regulated sensitively and quickly to adapt to the concentration of the substrate. Therefore, the independent transcription of cat $A$ might represent a positively selected genetic adaptation [3].

The intricate regulatory interplay of multiple cat gene clusters suggests an intimate mutual adaptation [45]. For instance, CatR is able to activate the $c l c A B D$ promoter but $C l c R$ cannot activate the cat $B C A$ promoter in $P$. putida PRS2000 [46]. As a result, transcription from the clc promoter is repressed by the TCA-cycle intermediates succinate, citrate and fumarate, while the presence of these organic acids does not affect the transcription from the cat promoter. This difference provides some flexibility to respond to different environmental signals in addition to the presence of the inducer [47]. Similarly, the question of how the two catBCA gene clusters are regulated in P. putida ND6 was investigated. We found that the core transcriptional activation mechanisms of the two orthocleavage operons are conserved. First, both can be induced by CCM. Second, $C_{a t} R_{I}$ and $C a t R_{I I}$ are the native regulatory proteins of the $c a t_{I}$ cluster and $c a t_{I I}$ cluster, respectively. Third, in the absence of CCM, CatR $\mathrm{I}_{\mathrm{I}}$ and CatR $\mathrm{R}_{\mathrm{II}}$ bind to the RBS, which contains a T/G- $\mathrm{N}_{11}$-A motif, presumably allowing CatR to negatively regulate its own expression, while in the presence of CCM, Cat $\mathrm{R}_{\mathrm{I}}$ and $\mathrm{Cat} \mathrm{R}_{\mathrm{II}}$ occupy an adjacent downstream site, designated as the ABS. Based on these conserved characters, $\mathrm{CatR}_{\mathrm{I}}$ and $\mathrm{CatR}_{\mathrm{II}}$ share functional similarities which allow them to complement each other's mutants at the transcriptional level. Different from CatR and ClcR of P.putida, CatR $\mathrm{R}_{\mathrm{I}}$ and $\mathrm{CatR}_{\mathrm{II}}$ can activate the promoters of the other, which provides another level of flexibility to respond to harmful mutations of each regulator. Additionally, EMSA demonstrated that CatR $\mathrm{R}_{\mathrm{I}}$ binds to both the $c a t_{I}$ and $c a t_{I I}$ promoters with high affinity, while $\mathrm{CatR}_{\mathrm{II}}$ binds weakly. These observations were confirmed by lac $Z$ transcriptional-fusion expression experiments, which indicated that $\mathrm{Cat}_{\mathrm{I}}$ might competitively bind the promoter region of $c a t$ and initiate transcription more effectively (Table 3 ). A mutation in the binding motif from T- $\mathrm{N}_{11}-\mathrm{A}\left(c a t_{I I}\right)$ to G-N $\mathrm{N}_{11}-\mathrm{A}\left(c a t_{I}\right)$ may explain the difference of binding characteristics. In conclusion, the two cat gene clusters in P. putida ND6 can cross-regulate each other as a result of similar evolutionary origins, but they diverged due to the accumulation of mutations that appear to be evolutionarily advantageous.

In this study, we found that the $\operatorname{cat} C_{I} /$ cat $_{I I}$ and $c a t A_{I} / c a t A_{I I}$ genes are transcribed independently, in addition to the co-transcription of the cat $B C A$ operon. We are conducting further experiments to demonstrate why and how the regulation of cat genes in P. putida ND6 is so complex.

\section{Acknowledgments}

This work was supported by the National Natural Science Foundation of China (Grant Nos. 21477163 and 31670512), and the Natural Science Basic Research Plan in Shaanxi Province of China (Grant No. 2018JM3039).

\section{Conflict of Interest}

The authors have no financial conflicts of interest to declare.

\section{References}

1. Linger JG, Vardon DR, Guarnieri MT, Karp EM, Hunsinger GB, Franden MA, et al. 2014. Lignin valorization through integrated biological funneling and chemical catalysis. Proc. Natl. Acad. Sci. USA 111: 12013-12018.

2. Mallick S. 2019. Biodegradation of acenaphthene by Sphingobacterium sp. strain RTSB involving trans-3-carboxy-2hydroxybenzylidenepyruvic acid as a metabolite. Chemosphere 219: 748-755.

3. Setlhare B, Kumar A, Mokoena MP, Olaniran AO. 2018. Catechol 1,2-Dioxygenase is an analogue of Homogentisate 1,2Dioxygenase in Pseudomonas chlororaphis Strain UFB2. Int. J. Mol. Sci. 20: 61.

4. Singh SN, Kumari B, Upadhyay SK, Mishra S, Kumar D. 2013. Bacterial degradation of pyrene in minimal salt medium mediated by catechol dioxygenases: enzyme purification and molecular size determination. Bioresour. Technol. 133: 293-300.

5. Wackett LP. 2003. Pseudomonas putida a versatile biocatalyst. Nat. Biotechnol. 21: 136-138.

6. Jimenez JI, Perez-Pantoja D, Chavarria M, Diaz E, de Lorenzo V. 2014. A second chromosomal copy of the catA gene endows Pseudomonas putida mt-2 with an enzymatic safety valve for excess of catechol. Environ. Microbiol. 16: 1767-1778.

7. Caposio P, Pessione E, Giuffrida G, Conti A, Landolfo S, Giunta C, et al. 2002. Cloning and characterization of two catechol 1,2dioxygenase genes from Acinetobacter radioresistens S13. Res. Microbiol. 153: 69-74.

8. Harwood CS, Parales RE. 1996. The beta-ketoadipate pathway and the biology of self-identity. 1996. Annu. Rev. Microbiol. 50: 553-590.

9. Tumen-Velasquez MP, Laniohan NS, Momany C, Neidle EL. 2019. Engineering CatM, a LysR-type transcriptional regulator, to respond synergistically to two effectors. Genes (Basel). 10: 421.

10. Parsek MR, Shinabarger DL, Rothmel RK, Chakrabarty AM. 1992. Roles of CatR and cis,cis-muconate in activation of the catBC operon, which is involved in benzoate degradation in Pseudomonas putida. J. Bacteriol. 174: 7798-7806.

11. Chugani SA PM, Hershberger CD, Murakami K, Ishihama A, Chakrabarty AM. 1997. Activation of the catBCA promoter: probing the interaction of CatR and RNA polymerase through in vitro transcription. J. Bacteriol. 179: 2221-2227. 
12. Tover A, Ojangu EL, Kivisaar M. 2001. Growth medium composition-determined regulatory mechanisms are superimposed on CatR-mediated transcription from the pheBA and catBCA promoters in Pseudomonas putida. Microbiology 147: 2149-2156.

13. Rothmel RK, Aldrich TL, Houghton JE, Coco WM, Ornston LN, Chakrabarty AM. 1990. Nucleotide sequencing and characterization of Pseudomonas putida catR: a positive regulator of the catBC operon is a member of the LysR family. J. Bacteriol. 172: $922-931$.

14. Kohlstedt M, Starck S, Barton N, Stolzenberger J, Selzer M, Mehlmann K, et al. 2018. From lignin to nylon: cascaded chemical and biochemical conversion using metabolically engineered Pseudomonas putida. Metab. Eng. 47: 279-293.

15. Pi H, Helmann JD. 2018. Genome-wide characterization of the fur regulatory network reveals a link between catechol degradation and bacillibactin metabolism in Bacillus subtilis. mBio 9: e1451-18.

16. Li S, Zhao H, Li Y, Niu S, Cai B. 2012. Complete genome sequence of the naphthalene-degrading Pseudomonas putida strain ND6. J. Bacteriol. 194: 5154-5155.

17. Li S, Qin K, Li H, Guo J, Li D, Liu F, et al. 2018. Cloning and characterisation of four catA genes located on the chromosome and large plasmid of Pseudomonas putida ND6. Electronic J. Biotechnol. 34: 83-90.

18. Kim SI, Leem SH, Choi JS, Chung YH, Kim S, Park YM, et al. 1997. Cloning and characterization of two catA genes in Acinetobacter lwoffii K24. J. Bacteriol. 179: 5226-5231.

19. Murakami S, Takashima A, Takemoto J, Takenaka S, Shinke R, Aoki K. 1999. Cloning and sequence analysis of two catecholdegrading gene clusters from the aniline-assimilating bacterium Frateuria species ANA-18. Gene 226: 189-198.

20. Suzuki K, Ichimura A, Ogawa N, Hasebe A, Miyashita K. 2002. Differential expression of two catechol 1,2-dioxygenases in Burkholderia sp. strain TH2. J. Bacteriol. 184: 5714-5722.

21. Tian M, Du D, Zhou W, Zeng X, Cheng G. 2017. Phenol degradation and genotypic analysis of dioxygenase genes in bacteria isolated from sediments. Braz. J. Microbiol. 48: 305-313.

22. Yoon YH, Yun SH, Park SH, Seol SY, Leem SH, Kim SI. 2007. Characterization of a new catechol branch of the beta-ketoadipate pathway induced for benzoate degradation in Acinetobacter lwoffii K24. Biochem. Biophys. Res. Commun. 360: 513-519.

23. Takashima A, Murakami S, Takenaka S, Aoki K. 2001. Regulation by two CatR proteins that differ in binding affinity to $c a t B$ promoters expressing two cat gene clusters. Biosci. Biotechnol. Biochem. 65: 2146-2153.

24. Ahn IS, Ghiorse WC, Lion LW, Shuler ML. 1998. Growth kinetics of Pseudomonas putida G7 on naphthalene and occurrence of naphthalene toxicity during nutrient deprivation. Biotechnol. Bioeng. 59: 587-594.

25. Sota M, Yano H, Ono A, Miyazaki R, Ishii H, Genka H, et al. 2006. Genomic and functional analysis of the IncP-9 naphthalenecatabolic plasmid NAH7 and its transposon Tn 4655 suggests catabolic gene spread by a tyrosine recombinase. J. Bacteriol. 188: 4057 4067.

26. Dennis JJ, Zylstra GJ. 2004. Complete sequence and genetic organization of pDTG1, the 83 kilobase naphthalene degradation plasmid from Pseudomonas putida strain NCIB 9816-4. J. Mol. Biol. 341: 753-768.

27. Li SS, Hu X, Zhao H, Li YX, Zhang L, Gong LJ, et al. 2015. Quantitative analysis of cellular proteome alterations of Pseudomonas putida to naphthalene-induced stress. Biotechnol. Lett. 37: 1645-1654.

28. Park W, Jeon CO, Hohnstock-Ashe AM, Winans SC, Zylstra GJ, Madsen EL. 2003. Identification and characterization of the conjugal transfer region of the pCg1 plasmid from naphthalene-degrading Pseudomonas putida Cg1. Appl. Environ. Microbiol. 69:3263-3271.

29. Hoang TT, Karkhoff-Schweizer RR, Kutchma AJ, Schweizer HP. 1998. A broad-host-range Flp-FRT recombination system for sitespecific excision of chromosomally-located DNA sequences: application for isolation of unmarked Pseudomonas aeruginosa mutants. Gene 212: 77-86.

30. Totten PA, Lory S. 1990. Characterization of the type a flagellin gene from Pseudomonas aeruginosa PAK. J. Bacteriol. 172: 7188-7199.

31. Green M R, Sambrook J. Molecular Cloning: A Laboratory Manual. 4th ed. Cold Spring Harbor Laboratory, 2012.

32. Li S, Li X, Zhao H, Cai B. 2011. Physiological role of the novel salicylaldehyde dehydrogenase NahV in mineralization of naphthalene by Pseudomonas putida ND6. Microbiol. Res. 166: 643-653.

33. Paulin MM, Novinscak A, St-Arnaud M, Goyer C, DeCoste NJ, Prive JP, et al. 2009. Transcriptional activity of antifungal metaboliteencoding genes phlD and $h c n B C$ in Pseudomonas spp. using RT-qPCR. FEMS Microbiol. Ecol. 68: 212-222.

34. Fekete RA, Miller MJ, Chattoraj DK. 2003. Fluorescently labeled oligonucleotide extension: a rapid and quantitative protocol for primer extension. Biotechniques 35: 90-94, 97-98.

35. Wang Y, Cen XF, Zhao GP, Wang J. 2012. Characterization of a new GlnR binding box in the promoter of amtB in Streptomyces coelicolor inferred a PhoP/GlnR competitive binding mechanism for transcriptional regulation of amtB. J. Bacteriol. 194: 5237-5244.

36. Chugani SA PM, Chakrabarty AM. 1998. Transcriptional repression mediated by LysR-type regulator CatR bound at multiple binding sites. J. Bacteriol. 172: 922-931.

37. Parsek MR, Ye RW, Pun P, Chakrabarty AM. 1994. Critical nucleotides in the interaction of a LysR-type regulator with its target promoter region catBC promoter activation by CatR. J. Biol. Chem. 269: 11279-11284.

38. Goethals K, Van Montagu M, Holsters M. 1992. Conserved motifs in a divergent nod box of Arhizobium caulinodans ORS571 reveal a common structure in promoters regulated by LysR-type proteins. Proc. Natl. Acad. Sci. USA 89:1646-1650.

39. Browning DF, Busby SJ. 2016. Local and global regulation of transcription initiation in bacteria. Nat. Rev. Microbiol. 14: 638-650.

40. Nojiri H, Maeda K, Sekiguchi H, Urata M, Shintani M, Yoshida T, et al. 2002. Organization and transcriptional characterization of catechol degradation genes involved in carbazole degradation by Pseudomonas resinovorans strain CA10. Biosci. Biotechnol. Biochem. 66: 897-901.

41. Kim SI, Ha KS, Leem SH. 1999. Differential organization and transcription of the cat2 gene cluster in aniline-assimilating Acinetobacter lwoffii K24. J. Biosci. Bioeng. 88: 250-257.

42. Vesely M, Knoppova M, Nesvera J, Patek M. 2007. Analysis of catRABC operon for catechol degradation from phenol-degrading Rhodococcus erythropolis. Appl. Microbiol. Biotechnol. 76: 159-168.

43. Chettri B, Singh AK. 2019. Kinetics of hydrocarbon degradation by a newly isolated heavy metal tolerant bacterium Novosphingobium panipatense P5:ABC. Bioresour. Technol. 294: 122190

44. Zhao H, Chen D, Li Y, Cai B. 2005. Overexpression, purification and characterization of a new salicylate hydroxylase from naphthalene-degrading Pseudomonas sp. strain ND6. Microbiol. Res. 160: 307-313.

45. Suvorova IA, Gelfand MS. 2019. Comparative genomic analysis of the regulation of aromatic metabolism in betaproteobacteria. Front. Microbiol. 10: 642

46. Parsek MR, McFall SM, Shinabarger DL, Chakrabarty AM. 1994. Interaction of two LysR-type regulatory proteins CatR and ClcR with heterologous promoters: functional and evolutionary implications. Proc. Natl. Acad. Sci. USA 91: 12393-12397.

47. McFall SM, Chugani SA, Chakrabarty AM. 1998. Transcriptional activation of the catechol and chlorocatechol operons: variations on a theme. Gene 223: 257-267. 